University of Nebraska - Lincoln

DigitalCommons@University of Nebraska - Lincoln

Conference Presentations and White Papers:

Biological Systems Engineering

Biological Systems Engineering

August 2006

\title{
Vegetative Treatment Systems for Open Lot Runoff: Review of Literature
}

Richard K. Koelsch

University of Nebraska - Lincoln, rkoelsch1@unl.edu

Jeffrey Lorimer

Department of Agricultural \& Biosystem Engineering, lowa State University

Kyle Mankin

Department of Biological and Agricultural Engineering, Kansas State University

Follow this and additional works at: https://digitalcommons.unl.edu/biosysengpres

Part of the Biological Engineering Commons

Koelsch, Richard K.; Lorimer, Jeffrey; and Mankin, Kyle, "Vegetative Treatment Systems for Open Lot Runoff: Review of Literature" (2006). Conference Presentations and White Papers: Biological Systems Engineering. 5.

https://digitalcommons.unl.edu/biosysengpres/5

This Article is brought to you for free and open access by the Biological Systems Engineering at DigitalCommons@University of Nebraska - Lincoln. It has been accepted for inclusion in Conference Presentations and White Papers: Biological Systems Engineering by an authorized administrator of DigitalCommons@University of Nebraska - Lincoln. 


\title{
VEGETATIVE TREATMENT SYSTEMS FOR OPEN LOT RUNOFF: REVIEW OF LITERATURE ${ }^{1}$
}

\author{
Richard Koelsch², Jeffery Lorimor ${ }^{3}$, Kyle Mankin ${ }^{4}$
}

\begin{abstract}
SUMMARY
Runoff from open lot livestock systems (beef and dairy) defined as Concentrated Animal Feeding Operations (CAFO) must be controlled by systems designed and managed to prevent the release of manure-contaminated runoff for storms equal to or less than a 25-year, 24-hour design storm. This performance standard has been attained for open lot systems with some combination of clean water diversion, settling basins, runoff collection ponds and irrigation systems (baseline system).

An alternative approach is to rely on overland flow and infiltration into cropland with perennial forage or grasses for treatment of open lot runoff. Such vegetative systems have been researched since the late 1960s. This paper reviews the research literature on vegetative treatment systems (VTS) for managing open lot runoff summarizing available science on system performance, design and management.

Based upon this review of the literature, the following conclusions are drawn about the application of VTS to manage runoff from open lot livestock production systems:

- Substantial research (approximately 40 identified field trials and plot studies) provides a basis for understanding the performance of VTS. A superior research knowledge base exists for performance of VTS as compared to baseline systems for CAFO regulation compliance.

- The baseline systems for CAFO regulation compliance perform well in the High Plains regions of the U.S. where significant moisture deficits exist (rainfall minus evaporation). However, the performance of these baseline technologies drops substantially for decreasing moisture deficits found in the central and eastern Corn Belt states. These trends have been established through computer modeling processes but not confirmed with in-field performance measurements.

- The existing research targeting VTS is confined to non-CAFO applications, likely due to past regulatory limits. Unique challenges exist in adapting these results and recommendations to CAFO applications.

- The pollutant reduction resulting from a VTS is based upon two primary mechanisms: (1) sedimentation, typically occurring within the first few meters of a VTS, and (2) infiltration of runoff into the soil profile. Systems relying primarily on sedimentation only are unlikely to perform equal or better than baseline technologies. System design based upon sedimentation and infiltration is necessary to achieve a required performance level for CAFO application.
\end{abstract}

\section{INTRODUCTION}

Runoff from open lot livestock production systems continues to be a contributor to surface water impairment. This literature review summarizes past research on Vegetative Treatment Systems $(\text { VTS })^{5}$ when applied to open lot systems. This alternative technology may potentially achieve the

${ }^{1}$ Reviewers: Robert Burns, Iowa State University, Saqib Mukhtar, Texas A\&M University, and Doug Hamilton, Oklahoma State University

${ }^{2}$ Department of Biological Systems Engineering and Animal Science, University of Nebraska

${ }^{3}$ Department of Agricultural \& Biosystem Engineering, Iowa State University

${ }^{4}$ Department of Biological and Agricultural Engineering, Kansas State University

${ }^{5}$ The terms VTS and VTA will both be used. Vegetative Treatment Area (VTA) applies to a cropped area with perennial grass or forage specifically designed to manage runoff from an open lot livestock facility. VTS will refer to the combination of treatment components including a VTA or Vegetative Infiltration Basin (VIB) and other possible treatment components (e.g., solids settling). 


\begin{tabular}{ll} 
& \multicolumn{1}{c}{ Abbreviations } \\
AMM & Animal Manure Management \\
BOD & Biochemical Oxygen Demand \\
CAFO & Concentrated Animal Feeding Operations \\
COD & Chemical Oxygen Demand \\
ELG & Effluent Limitation Guidelines \\
NPDES & National Pollution Discharge Elimination Systems \\
TS & Total Solids \\
U.S. EPA & United States Environmental Protection Agency \\
VTA & Vegetative Treatment Areas \\
VTS & Vegetative Treatment Systems \\
VIB & Vegetative Infiltration Basin \\
VS & Volatile Solids
\end{tabular}

same pollution control that is achieved by current United States Environmental Protection Agency (U.S. EPA), National Pollutant Discharge Elimination System (NPDES) technology-based standard. A VTS has the potential for providing control of pollution from feedlot runoff that is "functionally equivalent" to the conventional impoundment and land application system for Concentrated Animal Feeding Operations (CAFO).

The 2003 final federal rule for the NPDES Permit Regulation and Effluent Limitation Guidelines (ELG) and Standards for CAFOs (Federal Register, 2003) states that for Large CAFOs with dairy cows or beef cattle,

"(a) there must be no discharge of process wastewater pollutants into waters of the U.S. from the production area.

(1) Whenever precipitation causes an overflow of manure, litter, or process wastewater, pollutants in the overflow may be discharged into U.S. waters provided:

a) The production area is designed, constructed, operated and maintained to contain all manure, litter, and wastewater including runoff and the direct precipitation from a 25 year, 24-hour rainfall event;

b) The production area is operated in accordance with the additional measures and required by 412.37 (a) and (b)" (note: defines management and record keeping expectations).

(2) Voluntary alternative performance standards. Many CAFO subject to this Subpart may request the Director to establish NPDES permit effluent limitations based upon site-specific alternative technologies that achieve a quantity of pollutants discharged from the production area equal to or less than the quantity of pollutants that would be discharged under the standards as provided by paragraph (a)(1)..."

Part (1) sets the 25-year, 24-hour storm technology standard for baseline systems (runoff holding facilities dewatered by irrigation systems). Part (2) opens the door for alternative technology (such as a VTS) if they can be proven to achieve equal or less discharge of pollutants than the baseline technology (runoff holding pond plus irrigation). The "site-specific comparison" provision will place the burden of proof on the individual producer for comparing the baseline and alternative technology for individual farms.

\section{FEEDLOT RUNOFF CHARACTERISTICS}

Most research defining the characteristics of runoff from open livestock systems was completed in the 1960s through the 1980s. Based upon this research common characteristics have been published in accepted references from Natural Resources Conservation Service (Table 1), Texas Agricultural Extension Service (Table 2) and Experiment Stations of the North Central Regions land grant universities (Table 3). Original data for many of these reported values is from Linderman and Mielke (1975), Gilbertson et al. (1979), Swanson et al. (1971), Gilbertson and Nienaber (1973), Gilbertson et al. (1975) and Gilbertson et al. (1972). 
Table 1. Runoff holding pond effluent characteristics (Soil Conservation Service, 1992).

\begin{tabular}{|c|c|c|c|}
\hline Component & Units & $\begin{array}{l}\text { Runoff Pond } \\
\text { Supernatant }\end{array}$ & Sludge \\
\hline Total solids & \% w.b. & 0.30 & 17.20 \\
\hline Volatile solids & $\mathrm{kg} / 1000 \mathrm{~L}$ & 0.899 & 77.3 \\
\hline Fixed solids & $\mathrm{kg} / 1000 \mathrm{~L}$ & 2.10 & 94.4 \\
\hline COD & $\mathrm{kg} / 1000 \mathrm{~L}$ & 1.40 & 77.2 \\
\hline Nitrogen & $\mathrm{kg} / 1000 \mathrm{~L}$ & 0.20 & 6.19 \\
\hline Ammonium-N & $\mathrm{kg} / 1000 \mathrm{~L}$ & 0.18 & -- \\
\hline Phosphorus & $\mathrm{kg} / 1000 \mathrm{~L}$ & -- & 2.10 \\
\hline Potassium & $\mathrm{kg} / 1000 \mathrm{~L}$ & 0.90 & 1.70 \\
\hline \multicolumn{4}{|c|}{ Nitrogen content $(\mathrm{kg} \mathrm{N} / 1000 \mathrm{~L})$ of feedlot runoff at holding pond for: } \\
\hline Annual Rainfall & $\begin{array}{c}\text { Below Average } \\
\text { Conditions }\end{array}$ & $\begin{array}{c}\text { Average } \\
\text { Conditions }\end{array}$ & $\begin{array}{c}\text { Above Average } \\
\text { Conditions }\end{array}$ \\
\hline$<64 \mathrm{~cm}$ & 1.6 & 0.49 & 0.26 \\
\hline $64-89 \mathrm{~cm}$ & 0.26 & 0.13 & 0.066 \\
\hline$>89 \mathrm{~cm}$ & 0.066 & 0.044 & 0.022 \\
\hline \multicolumn{4}{|c|}{$\begin{array}{l}\text { Below Average: No settling facilities between the feedlot and pond. Feedlot topography and other characteristics are } \\
\text { conducive to high solids transport. High cattle density-more than } 620 \text { head/ha } \\
(250 \text { head } / \mathrm{ac}) \text {. } \\
\text { Average: Sediment traps, low-gradient channels, or natural conditions remove appreciable amounts of solids from } \\
\text { runoff before reaching the collection pond. Average runoff and solids transport characteristics. Average cattle } \\
\text { density-310 to } 620 \text { head/ha ( } 125 \text { to } 250 \text { head /ac). }\end{array}$} \\
\hline \multicolumn{4}{|c|}{$\begin{array}{l}\text { Above Average: Highly effective solid removal, such as vegetated filter strips or settling basins that drain liquid } \\
\text { waste through a pipe to storage pond. Low cattle density-less than } 310 \text { head/ha }(125 \text { head /ac). }\end{array}$} \\
\hline
\end{tabular}

Table 2. Average runoff characteristics from beef cattle feedyards in the Great Plains (Sweenten, 1991).

\begin{tabular}{|c|c|c|c|c|c|c|c|}
\hline Source & $\begin{array}{l}\text { Total } \\
\text { Solids, } \\
\text { ppm }\end{array}$ & $\begin{array}{c}\text { Electrical } \\
\text { Conductivity, } \\
\text { mmhos/cm }\end{array}$ & $\begin{array}{c}\text { Chemical } \\
\text { Oxygen } \\
\text { Demand, } \\
\text { ppm }\end{array}$ & $\begin{array}{c}\text { Total } \\
\text { Nitrogen, } \\
\text { ppm }\end{array}$ & $\begin{array}{c}\text { Total } \\
\text { Phosphorus, } \\
\text { ppm }\end{array}$ & $\begin{array}{c}\text { Sodium, } \\
\text { ppm }\end{array}$ & $\begin{array}{c}\text { Potassium, } \\
\text { ppm }\end{array}$ \\
\hline \multicolumn{8}{|l|}{ Feedlot Runoff $^{1}$} \\
\hline Average & 11,200 & 6,500 & 9,200 & 5800 & 1200 & 4400 & 200 \\
\hline Range & $\begin{array}{l}3,000- \\
17,500\end{array}$ & $3,200-8,600$ & $\begin{array}{l}2,200- \\
17,800\end{array}$ & $80-1,080$ & $50-300$ & $230-590$ & $340-1,320$ \\
\hline \multicolumn{8}{|l|}{ Pond Effluent } \\
\hline South Texas & 2,500 & 4500 & 1,100 & 180 & -- & 230 & 1,140 \\
\hline $\begin{array}{l}\text { Texas High } \\
\text { Plains }\end{array}$ & -- & 4,500 & 620 & 140 & 40 & 260 & 450 \\
\hline
\end{tabular}

\section{Runoff Quality}

Some generalizations about characteristics of feedlot runoff can be based upon this previously cited research:

- The solids fraction is roughly 10 times greater in runoff from snowmelt as compared to runoff from rainfall (Table 3).

- Volatile solids (VS) typically represent about $50 \%$ or less of total solids in runoff.

- Approximately 40 to $80 \%$ of solids in runoff will settle in settling basins designed with 30 minutes or greater retention capacity. 
Table 3. Livestock runoff quality characteristics (Nye, 1982).

\begin{tabular}{|c|c|c|c|c|c|c|}
\hline Source & $\begin{array}{c}\text { Total } \\
\text { Solids, } \\
\text { ppm }^{1}\end{array}$ & $\begin{array}{l}\text { Volatile } \\
\text { Solids, } \\
\text { ppm }^{1}\end{array}$ & $\begin{array}{c}\text { Chemical } \\
\text { Oxygen } \\
\text { Demand, } \\
\text { ppm }^{1}\end{array}$ & $\begin{array}{l}\text { TKN, } \\
\text { ppm }^{1}\end{array}$ & $\begin{array}{c}\text { Total } \\
\text { Phosphorus, } \\
\text { ppm }^{1}\end{array}$ & $\begin{array}{c}\text { Chloride, } \\
\text { ppm }^{1}\end{array}$ \\
\hline \multicolumn{7}{|l|}{ Beef } \\
\hline Rainfall & $2,100-200,000$ & $800-140,000$ & $500-20,000$ & $80-950$ & 500 & 220 \\
\hline Snowmelt & $9.3000-37,000$ & $5,000-24,000$ & $7,300-77,000$ & -- & $60-450$ & -- \\
\hline $\begin{array}{l}\text { Swine - } \\
\quad \text { Rainfall }\end{array}$ & -- & -- & $400-4,000$ & $50-180$ & $10-50$ & $50-170$ \\
\hline $\begin{array}{l}\text { Dairy - } \\
\text { Rainfall }\end{array}$ & $2,800-8,400$ & -- & $600-5,000$ & $30-400$ & $20-500$ & $40-400$ \\
\hline
\end{tabular}

- Increasing rainfall intensity leads to higher solids loss from the feedlot surface and greater VS or chemical oxygen demand (COD) concentration. Rainfall duration does not affect solids content of runoff.

- Ammonium and nitrate contents in the runoff decrease with continuing precipitation, indicating rapid leaching of these compounds from the feedlot surface.

- Phosphorus removal is closely related to solids removal and directly affected by rainfall intensity.

- Salt concentrations are the primary constituent of concern for crop performance that should be reviewed when runoff is used in land application.

\section{Runoff Quantity}

Maps for estimating design storm and average monthly runoff volumes are available from Chapter 10 of the Agricultural Waste Management Field Handbook (Soil Conservation Service, 1992). Some common observations relative to volume of runoff from open lots include the following:

- A linear relationship exists between runoff volume and rainfall (Figure 1). A rainfall event greater than $1 \mathrm{~cm}$ is necessary for runoff to occur. An average prediction equation was suggested by Clarke (et al., 1975):

$$
\text { Runoff }(\mathrm{cm})=0.56 \times \text { Precipitation }(\mathrm{cm})-0.84
$$

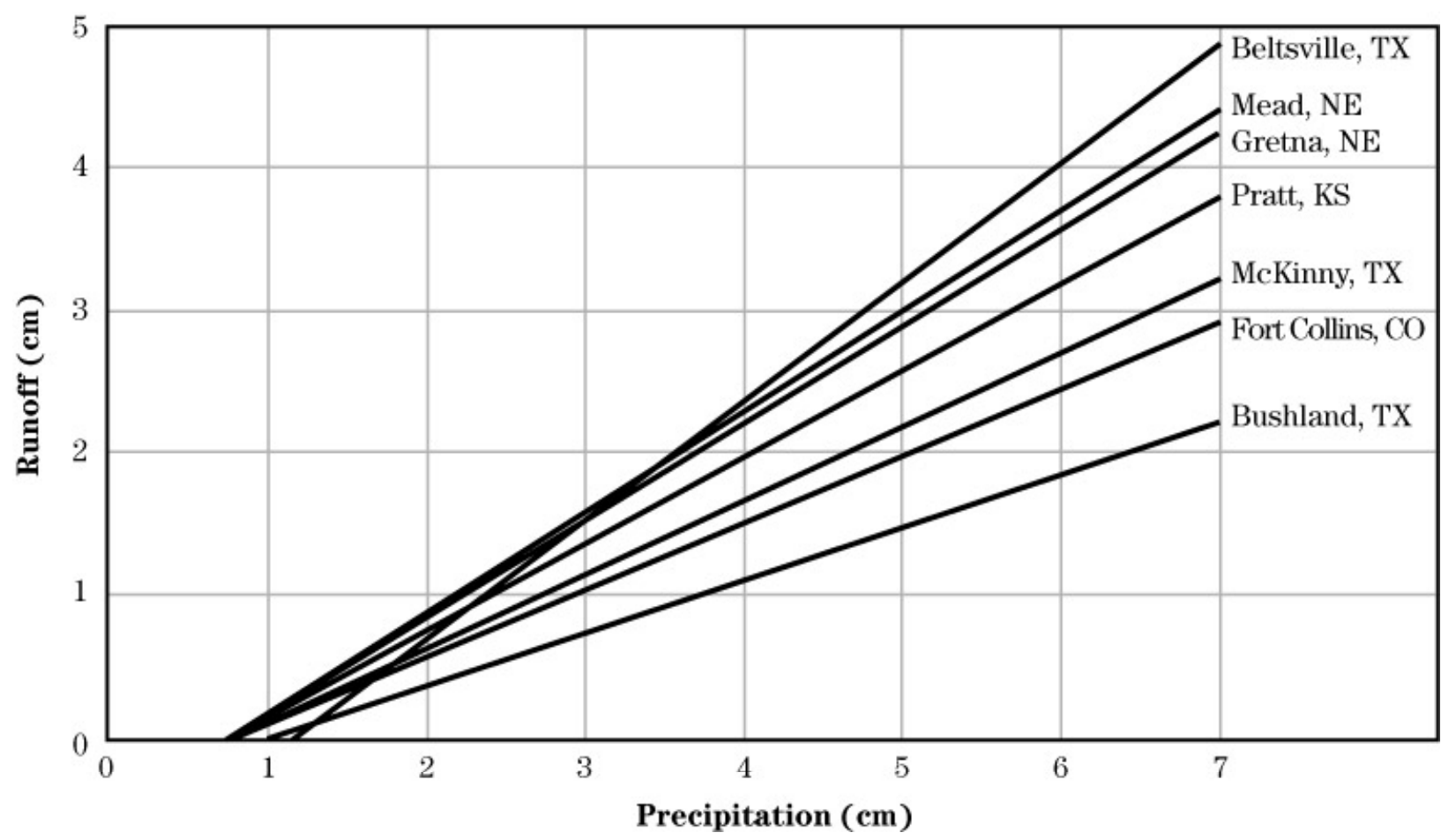

Figure 1. Precipitation-runoff relationships for beef cattle feedyards at seven locations in the Great Plains (Clarke et al., 1975). 
- A greater slope for the prediction equation should be used in regions with lower moisture deficit (rainfall - evaporation). This would suggest that higher rainfall regions should expect greater runoff volumes for the same size storm, a factor that is not included in current predictive equations (Clarke et al., 1975).

- Feedyard slope and stocking rates have little influence on runoff amounts (Gilbertson et al., 1970 and Clark et al., 1975);

- Lots that are wet the previous day have less runoff than dry lots due to depressions created by animal activity creating more opportunity for water retention on wet lots (Clarke et al., 1975).

The volume of runoff from a feedlot for a given storm is commonly estimated using the Natural Resources Conservation Service (NRCS) Curve Number method. This method is described in the NRCS National Engineering Handbook part 630 (Monkus, 1964). For the purpose of estimating the volume of storm runoff from a feedlot the following equation is solved for $\mathrm{Q}$ :

$$
\mathrm{Q}=\left(\mathrm{P}-0.2\left(\left(1000 / \mathrm{CN}_{1}\right)-10\right)\right)^{2} /\left(\mathrm{P}+0.8\left(\left(1000 / \mathrm{CN}_{1}\right)-10\right)\right)
$$

where

$\mathrm{Q}=$ volume of runoff in inches

$\mathrm{P}=$ rainfall in inches

$\mathrm{CN}_{1}=$ NRCS One Day Curve Number

A $\mathrm{CN}_{1}$ of 89 or 90 is commonly used for an unpaved feedlot, and a $\mathrm{CN}_{1}$ of 97 or 98 is commonly used for a paved feedlot.

\section{Pollutant Mass in Runoff}

In addition to knowledge of volume and concentration, total mass of nutrient and solids in runoff can be useful in design of settling basins and land application sites. Nutrient mass balance data has been collected on a set of University of Nebraska research beef cattle feedlot pens over approximately a five-year period (Erickson and Kissinger, 2004) representing 120 separate pens of cattle over the entire finishing period. This data would suggest that runoff after settling ${ }^{6}$ will contain 27 $\mathrm{kg}$ total solids, $0.68 \mathrm{~kg} \mathrm{~N}$ and $0.32 \mathrm{~kg}$ P per finished animal (Table 4).

Table 4. Mass of solids and nutrients in runoff from beef cattle feedlot pens (Erickson and Kissinger, 2004).

\begin{tabular}{|c|c|c|c|c|c|}
\hline & $\begin{array}{c}\text { Volume } \\
\text { (liters/ }\end{array}$ & Nitrogen & $\begin{array}{c}\text { Volatile } \\
\text { Phosphorus } \\
\end{array}$ & $\begin{array}{r}\text { Total } \\
\text { Solids } \\
\end{array}$ & Solids \\
\hline & finished animal) & & (kg/finishe & animal) & \\
\hline Runoff & 3554 & 0.68 & 0.32 & 13.37 & 27.38 \\
\hline Standard deviation & 2849 & 0.63 & 0.31 & 13.13 & 36.63 \\
\hline Estimated total excretion & & 25.00 & 3.30 & 290.00 & 360.00 \\
\hline$\%$ of excretion in runoff & & $2.7 \%$ & $9.8 \%$ & $4.6 \%$ & $7.6 \%$ \\
\hline Number of individual trials ${ }^{1}$ & 120 & 112 & 48 & 80 & 64 \\
\hline
\end{tabular}

\section{PERFORMANCE OF RUNOFF COLLECTION PONDS}

Since runoff from open lots is weather dependent, most in-field monitoring efforts are challenged to collect data over a sufficient time period to accurately predict the long-term performance of control technologies. The only efforts to predict runoff holding pond performance identified in the literature were based upon performance models. No field studies were identified that provided field measurements of performance for runoff holding ponds based upon a 25-year, 24-hour storm event design criteria or other related criteria. It would appear that once U.S. EPA established their technology-based ELG, no efforts have been made to document in-field performance of these design criteria.

\footnotetext{
${ }^{6}$ Settling basins were designed to hold all runoff until after a storm event for purpose of measurement of volume and collection of sample before release to a holding pond.
} 
Table 5. Performance of runoff control facility sized to hold runoff from an unsurfaced feedlot for a 25-year, 24-hour precipitation event as evaluated over a 30-year period

(Koelliker et al., 1975).

\begin{tabular}{|lcccc|}
\hline Location & $\begin{array}{c}\text { Runoff } \\
\text { Control (\%) }\end{array}$ & $\begin{array}{c}\text { Years with } \\
\text { Overflow }\end{array}$ & $\begin{array}{c}\text { Avg. Number of Days } \\
\text { with Overflow }\end{array}$ & $\begin{array}{c}\text { Number of Days with } \\
\text { Discharge over 30 years }\end{array}$ \\
\hline Northwest KS & 98.6 & 2 & 1.5 & 3 \\
Southwest KS & 100.0 & 0 & 0 & 0 \\
Central KS & 97.9 & 3 & 2.3 & 7 \\
Southeast KS & 95.5 & 9 & 3.6 & 47 \\
Northeast KS & 93.0 & 9 & 5.2 & 47 \\
\hline
\end{tabular}

Planning software titled "Animal Waste Management" (AWM) is maintained by USDA Natural Resources Conservation Service and commonly used for sizing of manure storage and runoff holding ponds (Wilson et al., 2003). An evaluation of the storage sized by AWM was compared against a water-balance model for storages using 30 years of weather data for 10 U.S. sites (Moffitt et al., 2003). The comparison revealed that 0 to $73 \%$ of the 30 years produced events requiring land application at shorter intervals than the design critical storage to maintain an acceptable storage volume for a 25-year, 24-hour storm. If pump-down during these periods did not occur, spillway flow would result during 0 to $40 \%$ of the modeled years. Management decisions during these periods when storage capacity was inadequate and sizing of the de-watering pump were two critical factors minimizing spillway flow.

A computer model developed by Kansas State University (Koelliker et al., 1975) predicts the portion of runoff controlled by a conventional runoff holding pond and irrigation system (sized to pump $10 \%$ of the holding pond volume per day). This model was used to evaluate a basin system for five Kansas sites and predicted that such systems perform better in more arid climates (Table 5). Full $(100 \%)$ control was predicted in southwest Kansas while only 93\% control (and 47 days of discharge over 30 years) was predicted for northeast Kansas. Discharges most commonly resulted from a series of precipitation events less than the design storm over an extended period of time when land application of liquid was judged to be not feasible (e.g., saturated soil conditions in landapplication site).

An Iowa State University application of the Kansas State model (Wulf et al., 2003 and 2004) provides additional support for the Kansas State observations. Based upon Iowa Department of Natural Resources minimum design criteria, five alternative design and management scenarios were modeled with 50 years of weather data for six Iowa locations. The resulting predictions suggested that between 70 and $90 \%$ of runoff could be controlled based upon a $25-\mathrm{yr}$, 24-hour storm design criteria with additional normal runoff storage requirement mandated by Iowa regulations 7 . The every event pump-out results (columns 2 and 3 in Table 6) compare favorably with the Kansas State results.

The predicted performance of the baseline system illustrated regular discharge occurrences for all scenarios evaluated. Northeast and East Central Iowa conditions produced the most frequent discharges and the lowest volume of runoff control. Land application systems that were not able to land apply runoff following each precipitation event were more likely to have discharge. Increasing volume of storage provided some reduction in runoff control but did not eliminate discharges (see Figure 2). The baseline system currently defined in the Effluent Limitations Guidelines (Federal Register, 2003) performs well under High Plains regional conditions, as found in western Kansas, but not nearly as well in regions with higher precipitation levels, extended wet periods, or less conducive to use of pivot irrigation systems.

To improve runoff control, it was further identified that extending the season for land application in the spring and fall produced the greatest benefits (Extended Pump-out Period results in Table 6).

\footnotetext{
${ }^{7}$ States may require storage capacity in addition to the minimum federal ELG requirement of a 25-year, 24-hour storm capacity. This additional capacity is typically sized to address average runoff over a pre-determined time. Iowa has established five methods for estimating this capacity based upon the planned schedule for dewatering of the holding pond.
} 
Table 6. Performance of runoff control facility sized to hold runoff from an unsurfaced feedlot designed based upon Iowa Department of Natural Resource criteria and evaluated over a 50-year period (Wulf et al., 2004).

\begin{tabular}{|c|c|c|c|c|c|c|}
\hline \multirow[b]{2}{*}{ Location } & \multicolumn{2}{|c|}{$\begin{array}{l}\text { Every Event } \\
\text { Pump-Out }\end{array}$} & \multicolumn{2}{|c|}{$\begin{array}{l}\text { April and Nov. } \\
\text { Pump-Out }\end{array}$} & \multicolumn{2}{|c|}{$\begin{array}{l}\text { Extended Pump- } \\
\text { Out Period }\end{array}$} \\
\hline & $\begin{array}{c}\text { Runoff } \\
\text { Control } \\
(\%) \\
\end{array}$ & $\begin{array}{c}\text { Overflow } \\
\text { Days }\end{array}$ & $\begin{array}{c}\text { Runoff } \\
\text { Control } \\
(\%) \\
\end{array}$ & $\begin{array}{c}\text { Overflow } \\
\text { Days }\end{array}$ & $\begin{array}{c}\text { Runoff } \\
\text { Control } \\
(\%)\end{array}$ & $\begin{array}{c}\text { Overflow } \\
\text { Days }\end{array}$ \\
\hline Northwest IA & 90.1 & 2.7 & 78.0 & 7.7 & 88.5 & 3.7 \\
\hline Southwest IA & 88.5 & 4.1 & 72.4 & 10.4 & 83.7 & 6.7 \\
\hline Central IA & 87.6 & 3.8 & 77.7 & 9.2 & 87.2 & 5.3 \\
\hline Southeast IA & 90.1 & 3.9 & 79.2 & 8.8 & 83.7 & 6.7 \\
\hline East Central IA & 82.3 & 6.1 & 64.5 & 13.4 & 80.3 & 7.8 \\
\hline Northeast IA & 81.3 & 6.0 & 66.5 & 12.9 & 87.3 & 5.6 \\
\hline $\begin{array}{l}\text { Basin capacity - } \\
\text { Amount of Runoff }\end{array}$ & \multicolumn{2}{|c|}{10 to $12 \mathrm{~cm}$} & \multicolumn{2}{|c|}{20 to $25 \mathrm{~cm}$} & \multicolumn{2}{|c|}{20 to $25 \mathrm{~cm}$} \\
\hline
\end{tabular}

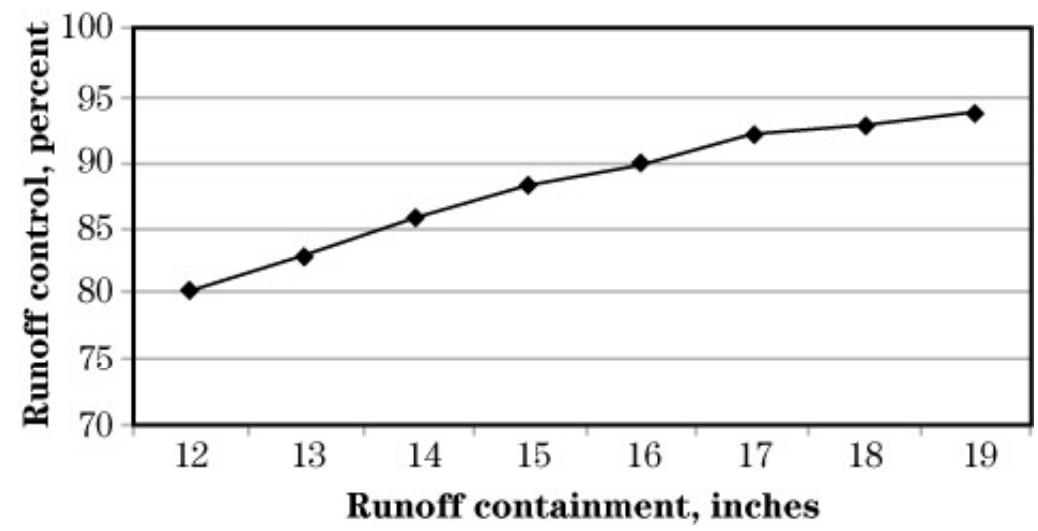

Figure 2. Effectiveness of adding storage capacity to containment basin. (Wulf et al., 2003).

Increasing pumping rate by 2.5 times or increasing storage capacity by $10 \%$ produced only minor improvements in increased runoff control (Wulf et al., 2003). Figure 2 illustrates the value of additional storage for a Central Iowa feedlot. Increasing total pond capacity from 30 to $48 \mathrm{~cm}$ (12 to 19 inches) of total runoff produced a reduction in the runoff control, but did not eliminate discharges.

A second Kansas State University study used the Koelliker model to estimate the baseline system volume necessary to provide $100 \%$ control of runoff based upon weather records for a 25 -year period (Anschutz et al., 1979). The volume of the holding basin varies substantially with location, as illustrated in Table 7. A holding pond for the same size feedlot will be between 3 and 6 times larger

Table 7. Relative size of runoff holding pond and land application system capable of pumping $2,850 \mathrm{~L} / \mathrm{min}$ or $750 \mathrm{gpm}$ during all seasons. Holding pond is sized to avoid all discharge based upon 25 years weather data (Anschutz et al., 1979).

\begin{tabular}{|c|c|c|c|c|c|}
\hline Location & $\begin{array}{c}\text { Pond Volume, } \\
\mathrm{m}^{3}\left(10^{6} \text { gal }\right)\end{array}$ & $\begin{array}{c}\text { Relative } \\
\text { Size to } \\
\text { Garden } \\
\text { City, KS }\end{array}$ & Location & $\begin{array}{c}\text { Pond Volume, } \\
\mathrm{m}^{3}\left(10^{6} \text { gal }\right)\end{array}$ & $\begin{array}{c}\text { Relative } \\
\text { Size to } \\
\text { Garden } \\
\text { City, KS } \\
\end{array}$ \\
\hline Garden City, KS & $17,376(4.6)$ & 1.0 & Wooster, $\mathrm{OH}$ & $226,853(60.0)$ & 13.0 \\
\hline Sacramento, CA & $57,760(15.3)$ & 3.3 & Minneapolis, MN & $56,374(14.9)$ & 3.2 \\
\hline Dublin, GA & $110,936(29.3)$ & 6.4 & Oklahoma City, OK & $38,771(10.2)$ & 2.2 \\
\hline Boise, ID & $19,980(5.3)$ & 1.1 & Centerville, SD & $51,478(13.6)$ & 3.0 \\
\hline W. Lafayette, IN & $103,946(27.5)$ & 6.0 & Hereford, TX & $23,998(6.3)$ & 1.4 \\
\hline Urbana, IL & $62,968(16.6)$ & 3.6 & College Station, TX & $54,761(14.5)$ & 3.1 \\
\hline Independence, KS & $37,186(9.9)$ & 2.1 & & & \\
\hline
\end{tabular}


in the central and eastern Corn Belt as compared to western Kansas. This assumes that the all locations would have access to dewatering capacity equal to a pivot application systems. Such systems are less commonly found in many regions outside of the High Plains states. With other land application methods, additional storage capacity would be needed to compensate for the slower dewatering rates. The study further observed a low correlation $\left(\mathrm{r}^{2}=0.33\right)$ between a $25-\mathrm{yr}, 24-\mathrm{hr}$ storm design criteria for pond sizing and the estimated "no-discharge" pond size based upon 25-year weather records. Moisture deficit was better correlated $\left(r^{2}=0.80\right)$ to the "no-discharge" pond size.

\section{VTS PERFORMANCE}

\section{Performance Models for VTS}

An Iowa State University VTS software modeling tool is designed to predict the performance of a site-specific VTS to meet the Voluntary Alternative Performance Standards (see Introduction) of the new EPA CAFO rules (Wulf et al., 2004). The VTS model performs site-specific modeling using daily weather inputs to estimate the performance of site-specific feedlots and VTS designs. The model is run for each of twenty-five weather years so that the performance of the alternative VTS (median outflow for 25-year period times pollutant concentration) can be compared to the performance of a baseline containment system at the same site following the procedures outlined by the Voluntary Alternative Performance Standards provisions of the CAFO regulations (Federal Register, 2003). At the time this literature review was prepared, model verification process was in progress.

Several Minnesota agencies have collaborated to develop a systematic procedure to identify appropriate applications of VTSs to feedlot runoff (Brach, 2003; Minnesota Pollution Control Agency, 2003). They have developed a standard identifying five levels of control (including VTA) and appropriate application of those five levels to individual situations based upon farm size and proximity to water. The team has developed a model, FLEVAL: An Evaluation System to Rate Feedlot Pollution Potential, to objectively evaluate feedlot pollution potential (http://www.bwsr .state.mn.us/outreach/engineering/fleval.html). Overcash et al. (1981) describes an additional model for predicting performance of a vegetative system located down-gradient from a manured land application site.

\section{Solids Removal Performance}

Solids removal via settling basins has been investigated for swine and bovine open lot runoff. Early studies of settling by Moore et al. (1973) using Imhoff cones showed that the majority of solids from beef feedlots settled within 10 minutes. From 10 minutes to 100 minutes only a slight improvement in settling was found. Fischer et al. (1975) concluded that the settling characteristics of hog manure are highly variable, but most settling occurs within the first 100 minutes. More recently Lott et al. (1994) examined solids in manure from Australian feedlots and differentiated two components: large particles that settled within 10 minutes and small particles that required extremely long settling times. The rapidly settling portion varied from 45 to $75 \%$ of the total solids. Sedimentation basin design based upon a maximum settling velocity of $0.003 \mathrm{~m} / \mathrm{s}$ was recommended by Lott et al. (1994).

A two-year study of settling basin performance below a swine facility and a beef feedlot in Iowa was conducted in the early 1990s (Lorimor et al., 1995). Solids in the swine runoff were reduced $29 \%$ from $3.1 \%$ to $2.2 \%$ wet basis. Solids concentration in the retained solids within the basin increased to an average of $12.7 \%$. On a mass basis the settling basin below the swine lot retained an average of $46 \%$ of the solids, $31 \%$ of the total Kjeldahl nitrogen (TKN), and $31 \%$ of total phosphorus $(\mathrm{P})$ over the two years of monitoring. Settling below the earthen beef feedlot in this study removed a mean of $64 \%$ of the total solids, $84 \%$ of the TKN, $80 \%$ of the total $\mathrm{P}$ and $34 \%$ of potas$\operatorname{sium}(\mathrm{K})$.

Woodbury et al. (2003a) reported total nitrogen mass reduction of about $45 \%$ for a settling basin on a central Nebraska beef cattle feedlot over a two-year period. Gilbertson and Nienaber (1973) observed that $71 \%$ of total solids that eventually settle will do so in the first 15 minutes representing $40 \%$ of total solids in runoff (Gilbertson et al., 1972).

Gilbertson et al. (1971) reported on performance of a batch system and a continuous-flow system for feedlot runoff. The batch system was more efficient in solids removal but suffered from management challenges including removal of settled solids. Dual settling basins were recommended to 
encourage greater drying and simplified solids management with solids-handling equipment. A continuous-flow system consisting of three porous dams in a settling channel recovered $50 \%$ of the total solids with $80 \%$ settling behind the first damn. Cold-weather solids settling proved a greater challenge, with solids remaining in a suspended form for longer periods at near-freezing temperatures. Only $42 \%$ of total solids were captured by the continuous-flow system during winter thaws.

Over a two-and-a-half-year period, Swanson and Mielke (1973) monitored a broad, flat channel with two or three galvanized hardwire meshes installed to settle solids from runoff. It was estimated that $80 \%$ of the total solids were removed during the period observed. Key design recommendations included: (1) channel length at least $6 \times$ the channel width, (2) channel depth should exceed screen height to permit emergency overflow, (3) first screen placement at $1 / 2$ to $1 / 3$ the length of channel from the inlet with additional screens equally spaced, (4) solids depth maximum of $38 \mathrm{~cm}$ (15 inches), and (5) inclusion of a hard-surface channel bottom to facilitate equipment operation.

The first component of any open feedlot runoff treatment system, whether it is total-containment system or alternative technology, should be solids settling, as is currently required by many state laws. Properly designed and managed solids settling basins should remove about $30 \%$ of the $\mathrm{N}$ and $\mathrm{P}$ from the runoff from swine lots and up to $80 \%$ of each from bovine lot runoff. Design recommendations for solids settling basins are available from MWPS (1985), Gilbertson and Nienaber (1973), and Sweeten (1991).

\section{Vegetative Treatment Areas (VTA) ${ }^{8,9}$}

This review of the literature assembled performance data from 16 research citations reporting 40 sets of performance data under field conditions (Table 9) and an addition 17 research citations reporting 61 sets of performance data under simulated conditions (Table 10). These research results are for both VTAs and Vegetative Infiltration Basins (VIB). The preponderance of the performance data is for a VTA. VTA efficiency is estimated in the literature by comparing the reduction of pollutant concentration and/or mass entering and leaving the VTA. Pollutants of concern in livestock runoff include solids, nitrogen, phosphorus and pathogens. In addition, summaries of performance observations beyond specific pollutant reductions are reported in Table 11.

Ikenberry and Mankin (2000) defined a VTA as a band of planted or indigenous vegetation situated down-slope of cropland or animal production facilities that provides localized erosion protection and contaminant reduction. Planted or indigenous vegetation is defined as pasture, grassed waterways, or cropland that is used to treat runoff through settling, filtration, adsorption, and infiltration. Murphy and Harner (2001) identified four primary approaches used in VTAs:

- Grass filters should be designed with a 1 to $4 \%$ slope and $61 \mathrm{~m}$ (200 feet) of filtering length per $1 \%$ slope. Total area should be designed to match crop nitrogen uptake with estimated $\mathrm{N}$ in runoff. Uniform flow across filtering slope is necessary, typically requiring laser-guided land leveling equipment.

- Constructed wetlands have been applied to open lot runoff. Design and management is challenged by the intermittent flow from open lots. The authors suggests that seasonal open lots used for winter livestock housing and empty during the summer may be a preferred system for constructed wetlands.

- Infiltration basins are a containment type of system with a 30 to $60 \mathrm{~cm}$ (12 to 24 inch) berm place around the vegetated area. They can be designed as discharge or non-discharge systems. The infiltration area necessary to infiltrate design runoff within 30 to 72 hours must be considered in sizing the infiltration basin area.

- Terraces, similar to infiltration basins, have been used to contain runoff on sloped areas. Both overflow and cascading terraces have been used. Overflow terraces move runoff from one terrace to an adjacent terrace at a lower elevation by cascading of runoff over the terrace top or by plastic tile drains. Serpentine terraces move runoff back and forth across the face of a slope. In both situations, the upper terrace is typically used for solids settling.

\footnotetext{
${ }^{8}$ See definition of VTA and VTS in footnote 5 on the first page of this paper.

${ }^{9}$ The author uses the terms VTA or vegetative treatment areas to represent the same technologies often referred to by other authors as vegetative filter strips. The author's choice of terminology differentiates VTAs applied to open lot livestock facilities from vegetative filter strips commonly used down gradient of cropland. Although both technologies share some similarities, there are distinctive differences in design and management.
} 
Table 11. Summary of performance observations for VTA for past research and field demonstration projects.

\begin{tabular}{|c|c|c|}
\hline Reference & Type of System & $\begin{array}{l}\text { Performance Observations (in addition to \% reductions re- } \\
\text { ported in Tables } 9 \text { and } 10 \text { ) }\end{array}$ \\
\hline $\begin{array}{l}\text { Barker and } \\
\text { Young, } 1984\end{array}$ & $\begin{array}{l}\text { Milking center wastewater and } \\
\text { open lot runoff from a } 54 \text { cow } \\
\text { dairy was directed to settling } \\
\text { basin and VTA. Four earthen } \\
\text { berms located at 30' intervals } \\
\text { were designed to create a cas- } \\
\text { cading type system. System } \\
\text { was monitored over two years. }\end{array}$ & $\begin{array}{l}\text { - Effluent leaving the VTA effluent was only 5\% of VTA influent } \\
\text { volume resulting is high pollutant mass reductions. } \\
\text { - Increased soil nitrates were observed in deep soil samples in sections } \\
\text { prior to first two berms. Increased soil P levels were also observed } \\
\text { ahead of first two berms. No other soil samples showed increases. } \\
\text { - Soluble salt concentration showed increases in all soil samples ahead } \\
\text { of first two berms. Total cations remained relatively constant with } \\
\text { exception of shallow soil samples taken ahead of first berm. } \\
\text { - VTA distribution pipe at upper end of field with four separate outlets } \\
\text { produced channel flow concerns. Increasing number of outlets to } \\
\text { seven appeared to reduce channel flow concerns. }\end{array}$ \\
\hline $\begin{array}{l}\text { Coyne et al., } \\
1998\end{array}$ & $\begin{array}{l}\text { Controlled replicated research } \\
\text { trials were conducted on VTA } \\
\text { of } 4.5 \text { and } 9.0 \mathrm{~m} \text { in length be- } \\
\text { low a simulated pasture area } \\
\text { with poultry manure added. A } \\
64 \mathrm{~mm} / \text { hour rainfall was ap- } \\
\text { plied. }\end{array}$ & $\begin{array}{l}\text { - } 85 \text { and } 76 \% \text { of total water runoff infiltrated into the } 9.0 \text { and } 4.5 \mathrm{~m} \\
\text { VFA plots, respectively. } \\
\text { - The } 4.5 \mathrm{~m} \text { VTA trapped most of the sediment in runoff. } \\
\text { - VTA of this length trapped most of the fecal bacteria that moved } \\
\text { onto the site. However, the concentration of fecal bacteria in runoff } \\
\text { remained high and exceeded water quality standards. }\end{array}$ \\
\hline $\begin{array}{l}\text { Chaubey et al., } \\
1995\end{array}$ & $\begin{array}{l}\text { Poultry manure applied to es- } \\
\text { tablished grass area with VTA } \\
\text { located below area of land } \\
\text { application. Site is subject to } \\
\text { simulated rainfall }\end{array}$ & $\begin{array}{l}\text { - First order linear regression describes reduction in mass transport of } \\
\text { litter constituents with VTA length. } \\
\text { - Removal of contaminants in VTA increased for lengths up to } 15.2 \\
\text { meters (ammonia and dissolved phosphorus), } 9.2 \mathrm{~m} \text { (total Kjeldahl } \\
\text { nitrogen and total phosphorus), and } 3.1 \mathrm{~m} \text { (total suspended solids and } \\
\text { chemical oxygen demand). } \\
\text { - VTA holds promise for improving quality of runoff from land appli- } \\
\text { cation sites treated with poultry litter. }\end{array}$ \\
\hline $\begin{array}{l}\text { Dickey and } \\
\text { Vanderholm } \\
1981 \mathrm{a}, \mathrm{b} ; \text { Van- } \\
\text { derholm and } \\
\text { Dickey, } 1980\end{array}$ & $\begin{array}{l}\text { Papers review design and per- } \\
\text { formance of four VTA, two } \\
\text { functioning as overland flow } \\
\text { ( } 100 \text { cow dairy and } 450 \text { beef } \\
\text { feedlot) and additional two as } \\
\text { channelized flow ( } 500 \text {-head } \\
\text { beef feedlot and } 480 \text {-head } \\
\text { swine operation) }\end{array}$ & $\begin{array}{l}\text { - VTA reduces nutrients, solids and organic matter from feedlot runoff } \\
\text { by over } 80 \% \text { on a concentration basis and } 95 \% \text { on a weight basis. } \\
\text { - Additional removals are impractical due to quality of runoff ap- } \\
\text { proaching that of agricultural land that is not exposed to feedlot run- } \\
\text { off. Discharge did not meet stream quality standards. } \\
\text { - Fecal coliform levels from the VTA with feedlot runoff addition } \\
\text { were one log higher than runoff from a control VTA with no manure } \\
\text { addition. Both were high in relation to stream standards. } \\
\text { - Most runoff events infiltrated completely, resulting in no discharge. } \\
\text { Sizing procedures used for project resulted in runoff only during } \\
\text { large precipitation events and high stream flows. }\end{array}$ \\
\hline $\begin{array}{l}\text { Dillaha et al., } \\
\text { 1988; Dillaha } \\
\text { et al., } 1986\end{array}$ & $\begin{array}{l}\text { Controlled replicated research } \\
\text { trials were conducted on VTA } \\
\text { of } 4.6 \text { and } 9.1 \mathrm{~m} \text { in length be- } \\
\text { low a simulated dairy open lot } \\
\text { of } 18.3 \text { meters on a silt loam } \\
\text { soil. A } 50 \mathrm{~mm} \text { /hour rainfall } \\
\text { was applied for two hours on } \\
\text { soils described as "dry", "wet" } \\
\text { and "very wet." }\end{array}$ & $\begin{array}{l}\text { - VTA are effective for removal of sediment and suspended solids } \\
\text { with filters of } 9.1 \text { m or less if flow is shallow and uniform. } \\
\text { - Some decline in effectiveness is noted with time as sediment accu- } \\
\text { mulates. } \\
\text { - Total N and P are not removed as effectively as sediment for the } \\
\text { lengths tested. } \\
\text { - VTA lengths used in this research were not effective in removing } \\
\text { soluble N and P. Soluble P was often higher in outflow than inflow, } \\
\text { presumably due to release of P previously trapped in the VTA. } \\
\text { - VTA with concentrated flow were significantly less effective than } \\
\text { were uniform flow plots. }\end{array}$ \\
\hline $\begin{array}{l}\text { Edwards } \\
\text { et al., } 1983\end{array}$ & $\begin{array}{l}\text { VTA test plots after settling } \\
\text { basin, natural rainfall, } 56 \text { head } \\
\text { of beef cattle on concrete lot. } \\
\text { Two grass filter cells were } \\
\text { used in series, each represent- } \\
\text { ing approximately } 50 \% \text { of the } \\
\text { concrete lot area. }\end{array}$ & $\begin{array}{l}\text { - Settling basin and filter strips reduced contaminant mass transport by } \\
81 \text { to } 89 \% \text {. } \\
\text { - The settling basin was more effective in large storm events. } \\
\text { - The grass filter strip was more effective when the basin was slowly } \\
\text { drained one day following a storm event. }\end{array}$ \\
\hline $\begin{array}{l}\text { Edwards } \\
\text { et al., } 1986 \\
\text { Fausey } \\
\text { et al., } 1988\end{array}$ & $\begin{array}{l}\text { VIB used with } 56 \text { head of beef } \\
\text { cattle on concrete lot. VIB was } \\
\text { preceded by solids settling } \\
\text { basin. }\end{array}$ & $\begin{array}{l}\text { - Infiltration basin approach eliminated all overland flow runoff to } \\
\text { receiving stream. } \\
\text { - Infiltration basin produced greater nutrient transport reduction than a } \\
33 \text { m grass filter strip but was less effective than a } 66 \text { m grass filter } \\
\text { strip. }\end{array}$ \\
\hline
\end{tabular}


- Reed canary grass thrived in the infiltration basin.

- Drain tile placed across the slope in the infiltration basin produced greater discharge volumes and greater pollutant transport from the drain tiles than a single drain tile placed parallel with the slope of the infiltration basin.

\begin{tabular}{|ll}
\hline Fajardo & VTA and fallow plots are \\
et al., 2001 & placed below area of manure \\
& application. Sufficient simu- \\
& lated rainfall was applied to \\
& achieve one-hour runoff event \\
& Much greater volumes were \\
& applied to VTA plots.
\end{tabular}

Harner and VTA established on several Kalita, 1999

Kalita, 1999

\begin{tabular}{|ll}
\hline $\begin{array}{l}\text { Hawkins } \\
\text { et al., 1998 }\end{array}$ & $\begin{array}{l}\text { Effluent pumped from swine } \\
\text { lagoon to VTA; runoff and } \\
\text { percolate analyzed }\end{array}$ \\
\hline
\end{tabular}

Hubbard Pre-treated swine lagoon ef-

et al., 1994; fluent was applied at a rate of

Hubbard $\quad 450$ and $900 \mathrm{~kg} / \mathrm{ha} / \mathrm{yr}$ to three

et al., 1999 VTA consisting of 1) 10-m wide grass (Bermuda and tall fescue) followed by $20-\mathrm{m}$ riparian zones, 2)10-m grass and 20 -m maidencane zones and 3) $20-\mathrm{m}$ grass and $10-\mathrm{m}$ riparian zones.

Pre-treated swine lagoon effluent was applied at a rate of $800 \mathrm{~kg} \mathrm{~N}$ and $150 \mathrm{~kg} P$ per ha per year to six different wetland and riparian plant species to evaluate plant response.

Lim et al., Cattle manure was applied to $1998 \quad$ upper $12.2 \mathrm{~m}$ of grassed plots. Runoff was collected at $0,6.1,12.2$, and 18.3 meters below area of manure application for simulated rainfall of $100 \mathrm{~mm} / \mathrm{hr}$.

Lorimor et Runoff from 380-head conal., 2003 crete feedlot passes through settling channel ( $1^{\text {st }}$ stage), infiltration basin ( $2^{\text {nd }}$ stage $)$, and wetlands ( $3^{\text {rd }}$ stage).
- Bacterial contamination in runoff water was not reduced when comparing tall fescue and fallow filter strips. Presence of bacterial organisms on the soil surface is ubiquitous. Manure addition did not significantly impact source of bacterial organisms.

- Dilution due to substantially greater water application in VTA to achieve similar runoff many also be partial explanation for reduced nitrates and unchanged coliform concentration. (author note: all comparisons are based only on concentration.)

- VTA effectively reduces nutrient, sediment, and bacteria from open lot livestock systems.

- Quality of vegetation impacts nutrient uptake capacity of VTA.

- Significant nitrification occurred on the steeper slope and elevated soil nitrate levels were a concern.

- Intense monitoring of nitrogen in soil, ground water, and surface water runoff was reported for a nine month period with no differences in treatments observed at this time.

- All three treatments sere effectively filtering $\mathrm{N}$ from applied swine manure at both rates.

- Significant reductions in ammonium in surface runoff were noted with down gradient distance from point of swine manure application. Nitrate concentration increased from less than $1 \mathrm{mg} /$ liter to between 1 and $15 \mathrm{mg} /$ liter.

- All species responded well to swine effluent application with buttonbush and saltmeadow cordgrass showing the greatest growth response.

- No concentration reductions were observed after first 6.1 meters.

- Concentration and mass transport reductions of the analyzed parameters followed a first-order exponential reduction relationship with length of VTA.

- Overall mass flow reductions have been between 86 and $98 \%$ for this system, with most significant reductions due to VIB.

- After five years of use, soil phosphorus levels within the infiltration basin have not shown signs of buildup.

- Although the flow out of the infiltration basin is not continuous, it has a substantially lower peak and extended period of flow as compared to the runoff flow from the feedlot. The infiltration basin also stores significant quantities of water subsequently used by plant growth thus reducing total volume. This change in flow pattern is beneficial to secondary treatment systems.

Mankin and 300-head heifer feedlot with Okoren, runoff directed to settling ba$2003 \quad \sin \left(1^{\text {st }}\right.$ stage $)$ and VTA $\left(2^{\text {nd }}\right.$ stage).

- Mass reduction of constituents occurred in first $30 \mathrm{~m}$. Little or no reduction occurred in last $120 \mathrm{~m}$.

- Fecal coliform concentration was reduced below accepted water quality standards.:

Nienaber et Settling basin, holding pond, al., 1974 sprinkler irrigation on grassed treatment area. Fresh water application compared with beef feedlot runoff.
- Application rates of $64 \mathrm{~cm}(25$ inches) in 1971 and $91 \mathrm{~cm}$ (36 inches) in 1972 did not result in runoff (applied mid spring through late fall) or accumulation of nitrogen, phosphorus, or chlorides. 


\begin{tabular}{|c|c|c|}
\hline $\begin{array}{l}\text { Paterson et } \\
\text { al., } 1980\end{array}$ & $\begin{array}{l}\text { Milking center waste and } \\
\text { barnyard runoff from } 70 \text { cow } \\
\text { dairy was directed through } \\
\text { settling basin }\left(1^{\text {st }} \text { stage }\right) \text {, hold- } \\
\text { ing tank with lift pump, and } \\
\text { VTA }\left(2^{\text {nd }} \text { stage }\right) .\end{array}$ & $\begin{array}{l}\text { - Four pollutants (BOD, NH4, PO4, and suspended solids) decreased } \\
\text { in concentration by passing though VTA. } \\
\text { - Four pollutants were reduced by } 97 \% \text { or more in perched ground } \\
\text { water while nitrate increased. } \\
\text { - Nitrate increased during passage through VTA except during win- } \\
\text { ter where nitrate was reduced in concentration. }\end{array}$ \\
\hline $\begin{array}{l}\text { Prantner et } \\
\text { al., } 2001\end{array}$ & $\begin{array}{l}\text { Undiluted swine manure, } 3 \text { to } \\
1 \text { swine manure and water, } \\
\text { and water applied to buried } \\
\text { containers with grass (first } \\
\text { stage) followed by wetland } \\
\text { plants ( } 2^{\text {nd }} \text { stage). Sufficient } \\
\text { manure or water volume ap- } \\
\text { plied at } 2 \text { week intervals to } \\
\text { saturate soil column. }\end{array}$ & $\begin{array}{l}\text { - Systems were designed to encourage nitrification followed by de- } \\
\text { nitrification processes and soil absorption and settling of phospho- } \\
\text { rus. The } 2 \text {-year study produced } 99.5 \text { and } 99.9 \% \text { reduction in am- } \\
\text { monium-N, } 98.5 \text { and } 99.8 \% \text { reduction in total P and ending nitrate } \\
\text { concentrations of } 0.2 \mathrm{mg} / 1 \text { (1998) and } 7 \text { to } 9 \mathrm{mg} / 1 \text { (1999). Similar } \\
\text { percentage of reduction of ammonium and phosphorus were ob- } \\
\text { served in the infiltration and wetland zones. Soil P accumulation } \\
\text { was a concern but not observed in } 2 \text { year study. }\end{array}$ \\
\hline $\begin{array}{l}\text { Sanderson } \\
\text { et al., } 2001\end{array}$ & $\begin{array}{l}\text { Solid dairy manure (1995) } \\
\text { and dairy lagoon effluent } \\
\text { (1996 and 1997) was applied } \\
\text { at rates ranging from } 0 \text { to } 600 \\
\mathrm{~kg} \mathrm{~N} / \text { ha in a replicate plot } \\
\text { design. Manure was applied to } \\
\text { a switch grass area with a } \\
\text { VTA consisting of switch } \\
\text { grass below the manured } \\
\text { plots. }\end{array}$ & $\begin{array}{l}\text { - VTA effectively reduced total reactive } \mathrm{P} \text { and COD concentrations } \\
\text { in surface runoff. } \\
\text { - Runoff concentration of N, P, and COD decreased as greater time } \\
\text { lapsed between manure application and precipitation event. To } \\
\text { minimize N and COD runoff concentrations, } 3 \text { to } 4 \text { days was sug- } \\
\text { gested. To minimize P concentrations, then } 1 \text { day was necessary. }\end{array}$ \\
\hline $\begin{array}{l}\text { Scheilinger } \\
\text { and } \\
\text { Clausen, } \\
1992\end{array}$ & $\begin{array}{l}\text { Concrete dairy barnyard run- } \\
\text { off flows through a detention } \\
\text { pond and into a } 22.9 \mathrm{~m} \text { by } 7.6 \\
\text { m VTA with } 2 \% \text { slope. }\end{array}$ & $\begin{array}{l}\text { - } 65 \% \text { of barnyard runoff exited from VTA. Retention of solids, N, } \\
\text { P, K, and bacteria was considered poor. } \\
\text { - Average hydraulic retention time of } 15 \text { minutes was observed. } \\
\text { - Inadequate detention time and excessive hydraulic detention times } \\
\text { were identified as reasons for poor performance. }\end{array}$ \\
\hline $\begin{array}{l}\text { Schmitt et } \\
\text { al., } 1999\end{array}$ & $\begin{array}{l}\text { Alternative lengths of VTA } \\
\text { and types of vegetation were } \\
\text { evaluated for agricultural field } \\
\text { runoff. }\end{array}$ & $\begin{array}{l}\text { - VTA performance is strongly dependent upon type of contami- } \\
\text { nants. VTA are most effective for sediment related contaminants } \\
\text { and least effective for dissolved contaminants. } \\
\text { - Doubling filter strip from } 7.5 \text { to } 15 \mathrm{~m} \text { does not improve sediment } \\
\text { settling, increases infiltration, and increases dilution of runoff. } \\
\text { - Incorporating trees and shrubs into the lower half of filter strips } \\
\text { does not affect performance. } \\
\text { - Contour sorghum strips of equal width are not as effective at re- } \\
\text { ducing contaminants as perennial vegetation. }\end{array}$ \\
\hline $\begin{array}{l}\text { Schwer and } \\
\text { Clausen, } \\
1989\end{array}$ & $\begin{array}{l}\text { VTA was designed to treat } \\
\text { milk house wastewater on a } \\
\text { Vermont Dairy. }\end{array}$ & $\begin{array}{l}\text { - Retention was greatest during the growing season and least during } \\
\text { snow melt. } \\
\text { - Retention of N \& P in harvested crops accounted represented only } \\
\text { a small portion of input nutrients. }\end{array}$ \\
\hline $\begin{array}{l}\text { Srivastava } \\
\text { et al., } 1996\end{array}$ & $\begin{array}{l}\text { Nine control VTA plots, rang- } \\
\text { ing from } 3 \text { to } 18.3 \mathrm{~m} \text {, were } \\
\text { placed after poultry manure } \\
\text { amended pasture }\end{array}$ & $\begin{array}{l}\text { - Pollutant concentration of water exiting litter treated areas is not } \\
\text { dependent on litter treated length, suggested rapid equilibrium be- } \\
\text { ing reached. } \\
\text { - Pollutant concentrations decreased with increasing VTA length for } \\
\text { all pollutants. } \\
\text { - Mass transport was not affected by VTA length with large portion } \\
\text { of the mass removal occurring within the first } 3 \text { m of VTA. }\end{array}$ \\
\hline $\begin{array}{l}\text { Willrich } \\
\text { and Boda, } \\
1976\end{array}$ & $\begin{array}{l}\text { Anaerobic lagoon swine ef- } \\
\text { fluent is applied to upper end } \\
\text { of six plots. }\end{array}$ & $\begin{array}{l}\text { - Overland flow treatment of swine lagoon effluent caused signifi- } \\
\text { cant concentration attenuations and mass reductions of its polluting } \\
\text { properties. } \\
\text { - BOD and turbidity removal became effective with time whereas } \\
\text { treatment effectiveness for COD, phosphorus, salinity and ammo- } \\
\text { nia decreased with time. } \\
\text { - Changes in application rate impacted runoff volumes but did not } \\
\text { significantly change concentration of most contaminants. } \\
\text { - Significantly greater attenuation occurred during cool, wet months } \\
\text { for turbidity and fecal coliform and during warm, dry months for } \\
\text { phosphorus. Nitrification was also greater during warn, dry } \\
\text { months. }\end{array}$ \\
\hline
\end{tabular}




\begin{tabular}{|c|c|c|}
\hline $\begin{array}{l}\text { Woodbury } \\
\text { et al., 2002, } \\
2003 \mathrm{a}, \\
2003 \mathrm{~b}\end{array}$ & $\begin{array}{l}\text { Runoff from eight open lot } \\
\text { beef cattle pens (about } 600 \\
\text { cattle) moved from the pens } \\
\text { through a grass approach, } \\
\text { settling basin (created by a } \\
300 \text { m long terrace below the } \\
\text { pens), and a } 6 \text { ha VTA ). }\end{array}$ & $\begin{array}{l}\text { - The settling basin removed } 80,67,59 \text {, and } 47 \% \text { of the total sus- } \\
\text { pended solids, volatile suspended solids, chemical oxygen demand, } \\
\text { and total nitrogen. } \\
\text { - Distribution of settling basin water to a VTA was not uniform re- } \\
\text { sulting in soil nitrate accumulation in upper } 30 \mathrm{~cm} \text { ( } 1 \text { foot). } \\
\text { - No water was measured exiting the VTA below the root zone or at } \\
\text { the down gradient end of the VTA over a three-year period sug- } \\
\text { gesting hay crop utilization of all applied water. } \\
\text { - Mass nitrogen removal by harvesting exceeded mass nitrogen ad- } \\
\text { dition with feedlot runoff. } \\
\text { - Migration of nitrate below the settling basin is a problem, possibly } \\
\text { exacerbated by solids removal and basin cleaning. }\end{array}$ \\
\hline $\begin{array}{l}\text { Young et } \\
\text { al., } 1980\end{array}$ & $\begin{array}{l}\text { Rainfall simulator applied } 25 \text { - } \\
\text { year, 24-hour storm to VTA } \\
\text { plots containing corn, orchard } \\
\text { grass, sorghum-Sudan grass } \\
\text { mix, oats over } 2 \text { year test pe- } \\
\text { riod. }\end{array}$ & $\begin{array}{l}\text { - Significant reductions on nitrogen forms (with exception of ni- } \\
\text { trate), phosphorus, and microorganisms were observed for } 36 \mathrm{~m} \\
\text { VTA. } \\
\text { - Nonstructural control practices are a promising alternative method } \\
\text { for controlling feedlot runoff. }\end{array}$ \\
\hline $\begin{array}{l}\text { Younos et } \\
\text { al., } 1998\end{array}$ & $\begin{array}{l}18 \text { m wide VTA placed down } \\
\text { gradient from open lot for } 60- \\
\text { head dairy. }\end{array}$ & $\begin{array}{l}\text { - Stream loads for total runoff, orthophosphate and dissolved phos- } \\
\text { phorus, total phosphorus, and total nitrogen were lower after VTA } \\
\text { installation as compared to a pre-VTA installation. However, due } \\
\text { to the relatively short monitoring ( } 6 \text { months prior and after installa- } \\
\text { tion), differences were statistically inconclusive. } \\
\text { - Although the water quality upstream of the sacrifice lot is already } \\
\text { degraded, the installation of the VTA may prevent a further degra- } \\
\text { dation of the water quality downstream of the sacrifice lot. }\end{array}$ \\
\hline
\end{tabular}

VTAs provide an opportunity for reduction of pollutants in runoff through two primary mechanisms: (1) sedimentation, typically occurring within the first few meters of a VTA, and (2) infiltration of runoff into the soil profile (Pope and Stolenberg, 1991). The soil system also provides a physical structure and biological environment for treatment of pollutants including filtration (e.g., restricting movement of most protozoa and bacteria), immobilization (e.g., soil cations immobilizing ammonium), aerobic processes (e.g., conversion of organic compounds to water and carbon dioxide), and anaerobic process ( e.g., conversion of nitrates to nitrogen gas). The VTA also allows the recycling of nutrients by plants (Fajardo et al., 2001).

VTA flow can be classified as either channelized or uniform flow (Dickey \& Vanderholm, 1981a). Their work showed that "the channelized flow system required a flow length over 5 times longer than the overland flow systems to achieve a similar concentration reduction." Dillaha et al. (1988) studied concentrated flow effects on removal efficiencies and found that lower removal efficiencies occurred in VTAs with concentrated flows than in VTAs with shallow, uniform flow.

Surface flow in channelized-flow VTAs concentrates into channels. One can more clearly define these as gullied or preferential-flow systems. If gullied or preferential flow develops, non-uniform loading of VTA will reduce performance of the system due to soil erosion and reduced utilization of the VTA area. Uniform-flow systems allow a uniform loading of waste (across the width of the VTA) at a relatively shallow depth $(<4 \mathrm{~cm})$. Uniform depth across the entire width of the VTA results in a slower velocity through the system, allowing sediment and nutrients to be trapped by the vegetation and adsorbed by the soil, and ultimately more efficient removal of nutrients and sediment from the waste stream.

Dickey and Vanderholm (1981b) showed progressively better removal of $\mathrm{N}$ and ammonium $\left(\mathrm{NH}_{4}{ }^{+}\right)$over 100 meters $(300 \mathrm{ft})$ of overland flow in a VTA for a 100-head dairy and 500-head beef lot as shown in Figure 3. Lim et al. (1997) and Chaubey et al. (1995) demonstrated a first-order exponential relationship better described the interaction between VTA length and pollutant transport. Data from 10 separate studies conducted over the last 25 years (Figure 4) show that $80 \%$ reductions of TKN and total P are achievable as a function of the ratio of VTA area to the feedlot drainage area (VTA:DA).

\section{Solids Removal}

Extensive research has been conducted on solids removal by VTA. Total solids are commonly reduced by $70-90 \%$ (Table 9 and 10). Variations occur due to site-specific conditions such as vege- 


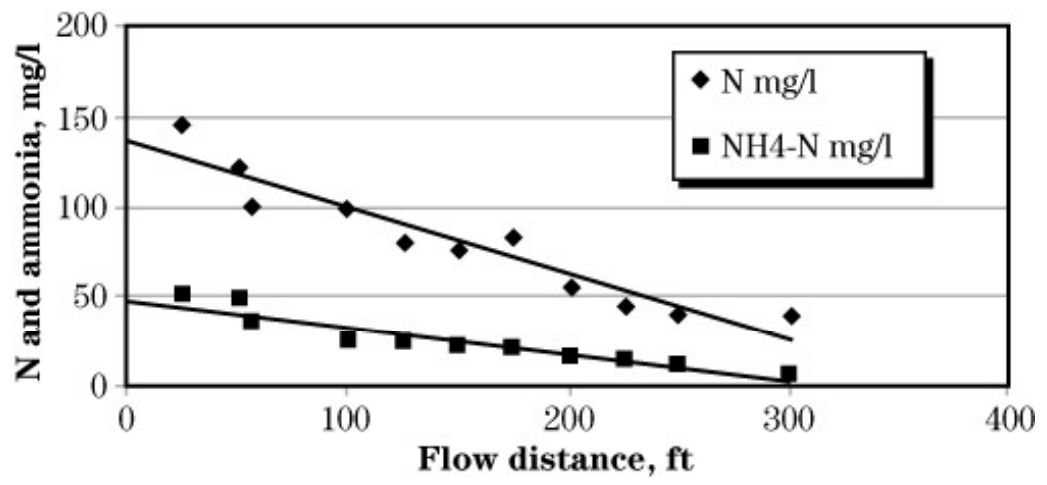

Figure 3. Effect of VTA length on TKN and ammonia N reduction (Dickey \& Vanderholm, 1981a).
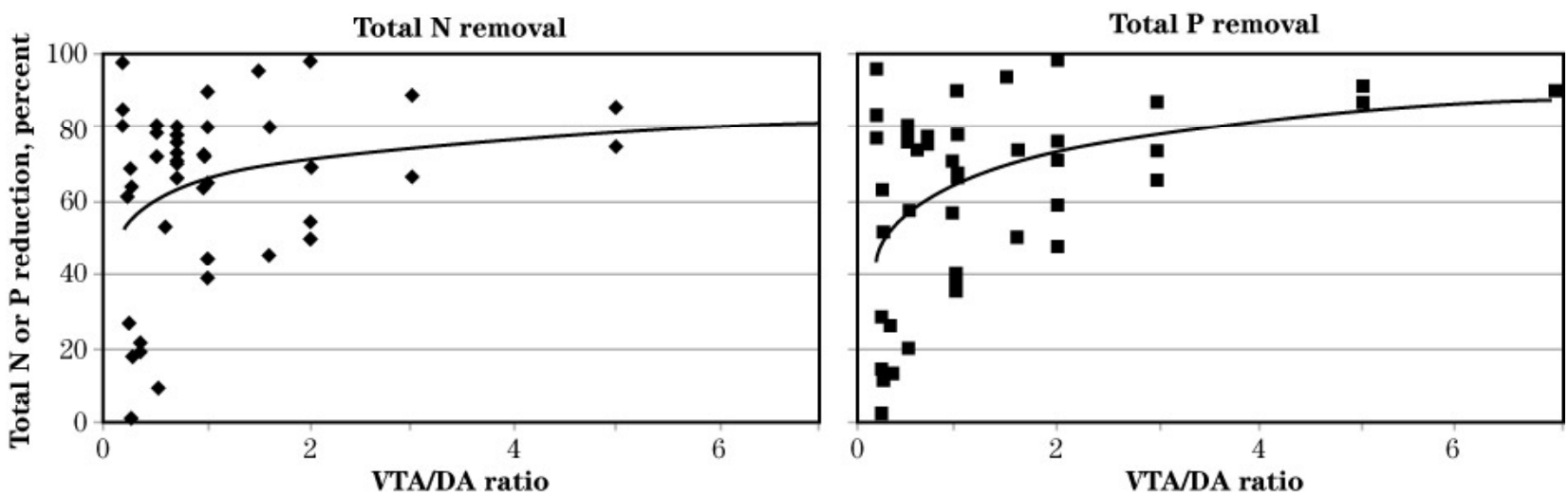

Figure 4. Nutrient removal by VTA based upon VTA to discharge area (DA) ratio for references listed in Tables 6 and 7.

tation, slope, soil type, size and geometry of filter strip, and influent solids concentration. When receiving runoff directly from a feedlot, VTAs remove most solids within the first few meters of the filter strip. Coyne et al. (1998) found most reductions in concentration occurred in the first 4.5 meters. Chaubey et al. (1995) showed improved P removal effectiveness from swine lagoon effluent with increased VTA length up to 9 meters $(30 \mathrm{ft})$. Solids reduction would likely perform in a similar manner. Chaubey et al. (1995) noted that removal of total suspended solids and chemical oxygen demand in VTA increased for lengths up to $3.1 \mathrm{~m}$. This quick reduction can be attributed to a significant reduction in flow velocity due to vegetation retarding the flow and producing soil conditions conducive to infiltration.

\section{Fecal Coliform Removal}

More research on fecal coliform (FC) removal by VTAs is needed. Reported values vary greatly and few studies have been conducted on large scale VTAs. Fajardo et al. (2001) report FC removal rates between $64 \%$ and $87 \%$ when using small-scale simulated runoff events with stockpiled manure. Lim et al. (1997) found that all fecal coliforms were removed in the first $6.1 \mathrm{~m}$ of a VTA used to treat runoff from a simulated pasture. Average $\mathrm{FC}$ removal in the studies reported was $76.6 \%$ (Ikenberry and Mankin, 2000). A model for describing fecal pathogens in vegetative filter strips was being assembled by Zhang et al. (2001) and linked to an existing model of VTA hydrology and sediment transport, although data were not available to test the model at the time this research paper was prepared.

\section{Nitrogen Removal}

The most common gauges of nitrogen content in surface runoff include total nitrogen (TN), total Kjeldahl nitrogen (TKN), ammonium and ammonia nitrogen $\left(\mathrm{NH}_{4}\right.$ and $\mathrm{NH}_{3}$, respectively), and nitrate $\left(\mathrm{NO}_{3}\right)$ (Ikenberry and Mankin, 2000). Removal of TN, TKN, $\mathrm{NH}_{4}$, and $\mathrm{NH}_{3}$ by VTA, has been shown to exceed $85 \%$. Nitrate removal has typically been much lower, although Fajardo et al. (2001) reported 97 and 99\% reductions in simulated VTA studies. In some studies $\mathrm{NO}_{3}$ increased from nearzero levels typical of most anaerobic feedlot runoff, to below health limit levels during flow through the VTA. Chaubey et al. (1995) noted that removal of ammonia and TKN in VTA increased for lengths up to 15.2 and 9.2 meters, respectively. Overall properly designed and managed VTAs are very effective, averaging approximately $70 \%$ nitrogen removal (Ikenberry and Mankin, 2000). 


\section{Phosphorous Removal}

Because the majority of the phosphorous in feedlot runoff is adsorbed to solids particles, total phosphorous removal is directly related to solids removal efficiencies. Phosphorous removal rates have ranged from 12-97\%, averaging about 70\%. Chaubey et al. (1995) also noted that removal of dissolved and total phosphorus in VTA increased for lengths up to 15.2 meters and $9.2 \mathrm{~m}$, respectively.

\section{Vegetative Infiltration Basin (VIB)}

Most VTA systems are designed as grass filters with little or no berming within the flow path to limit runoff when the system becomes saturated. Vegetative systems force infiltration of runoff through a soil filter and provide an alternative approach that prevents surface-water discharges. Lorimor et al (2003) operated a bermed infiltration area that allowed discharges only through subsurface drain tiles placed $1.8 \mathrm{~m}$ (6 feet) below the surface of this basin. All runoff must move through a soil filter prior to discharge. The smaller footprint for the VTA (1/6 to 1/12 of most standard VTA designs) and no direct surface-water discharge are two advantages. After five years of experience, soil $\mathrm{P}$ levels have not shown signs of buildup. Preferential flow through the soil filter may be a potential concern over time. Infiltration basins represent an alternative VTA design that out-performs most grass filters but may be acceptable only for sites with low-infiltration clay layers below the drain tile. Edwards et al. (1986 and 1988) have reported operation of an infiltration basin below a small open lot cattle facility (see results in Table 9).

As wastewater infiltrates the soil, aerobic nitrification occurs, converting ammonium to nitrate by the aerobic bacteria Nitrosomonas and Nitrobacter (Prantner et al., 2001). In addition, phosphorus interacts and becomes attached to soil particles in the profile. Field drainage tile is used to intercept the filtrate and carry it to a secondary form of treatment such as a constructed wetland or VTA.

Two recent infiltration studies at Iowa State University have shown significant water quality improvements. Using liquid swine manure, Prantner et al. (2001) showed over 93\% reductions in $\mathrm{NH}_{4}-\mathrm{N}$, and $89 \%$ reduction in P. Yang and Lorimor (2000) reported a field infiltration system down gradient of a 380 -head concrete beef feedlot. Over two years of sampling they found an $81 \%$ reduction in suspended solids, $83 \%$ reduction in TKN, an $85 \%$ reduction in $\mathrm{NH}_{4}-\mathrm{N}$, and a $78 \%$ reduction in P. Nitrate levels have increased by $87 \%$ suggesting a need for nitrate utilization or treatment downstream of an infiltration system.

Infiltration basins based upon soil filters are limited to sites conducive to tile drainage where a restrictive soil layer exists below the surface restricting water and contaminant movement to ground water. Alternative infiltration systems, such as a constructed infiltration bed of sand, biosolids and wood chip mixtures laid over a gravel layer with a tile drain used to treat runoff from paved parking lots (Culbertson and Hutchinson, 2004), may have application to livestock systems.

Another advantage of an infiltration basin is its ability to alter the flow rate and timing of liquid exiting the infiltration basin (Lorimor et al., 2003). Slowing the flow from the infiltration basin during the storm event and delaying much of the discharge until after the storm event enhances the potential for successful treatment in later treatment components such as a VTA.

\section{Overall VTS Performance}

By coupling various combinations of treatments into a treatment system, the quality of feedlot runoff can be significantly improved to the point of achieving "functional equivalency" to baseline technologies to complete elimination of surface water runoff. Although the particular combination of treatments selected for any feedlot will be site specific, essentially all should begin with solids settling. Table 8 shows a summary of the anticipated contaminant reductions discussed previously plus common performance levels for constructed wetlands.

Table 8. Summary of contaminant concentration reductions for various treatment components associated with a dairy or beef open lot facility. Reductions for two or more components can be estimated by multiplying remaining contaminants $(1$ - reduction) for each component. A settling basin and VIB will reduce concentration by $92 \%$ or $100-[(100-60) \times(100-80)]$.

\begin{tabular}{|cccccc|}
\hline & Total Solids & TKN & Ammonium- N & Total P & BOD \\
\hline Settling & 60 & 80 & 80 & 80 & --- \\
VTA & 60 & 70 & 70 & 70 & 75 \\
VIB & 80 & 80 & 85 & 80 & \\
Wetland & 60 & 50 & 50 & 50 & 60 \\
\hline
\end{tabular}




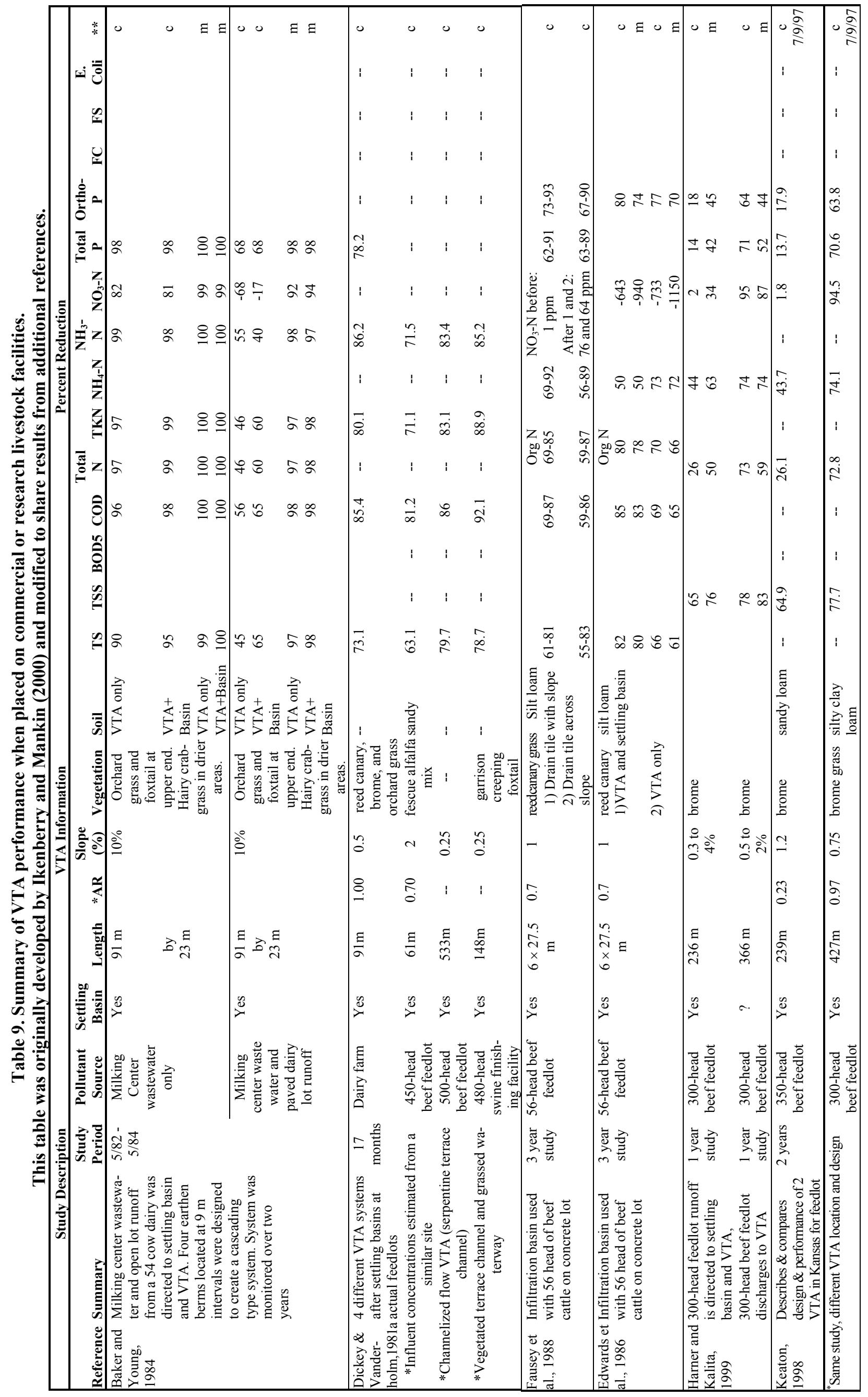




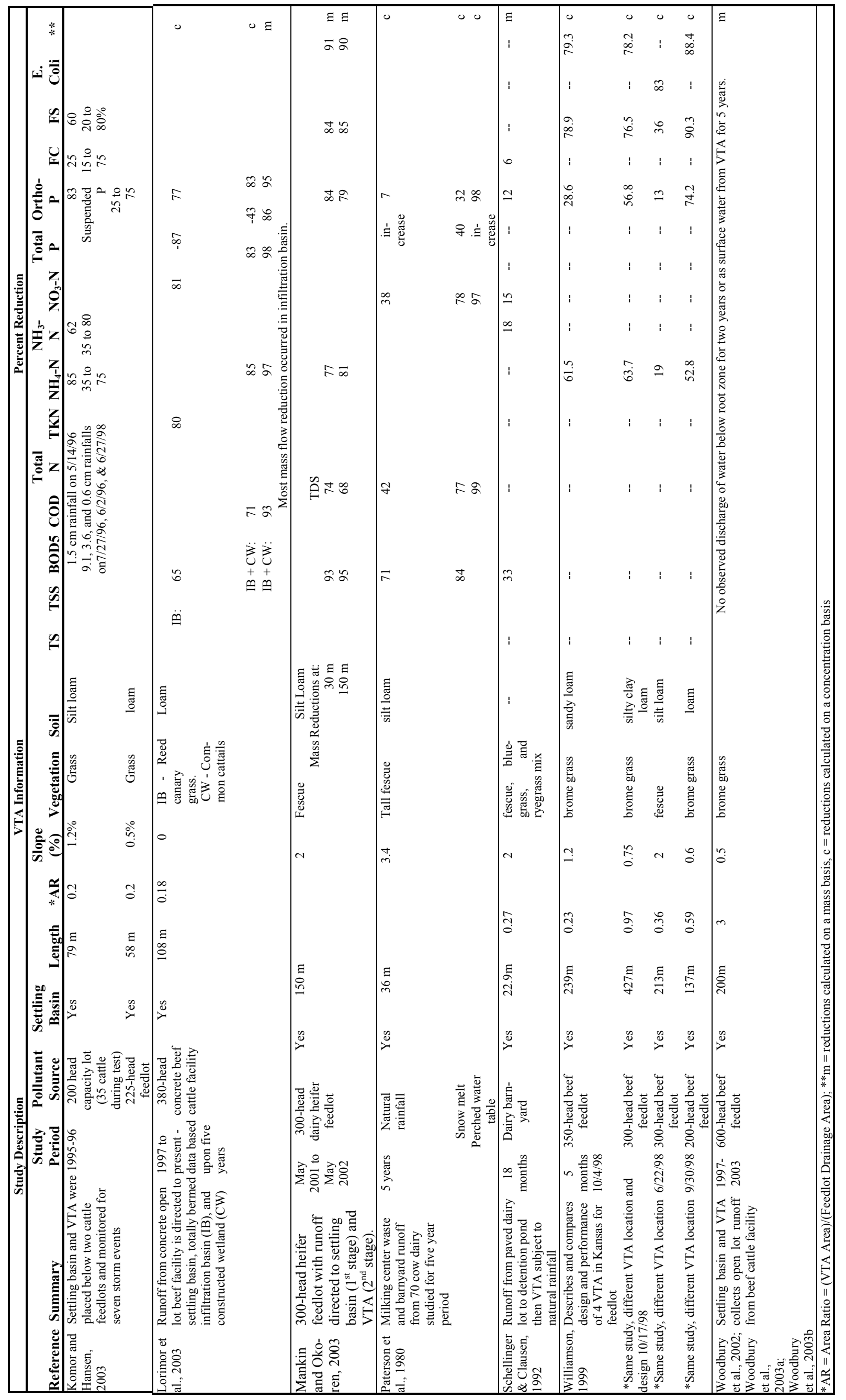




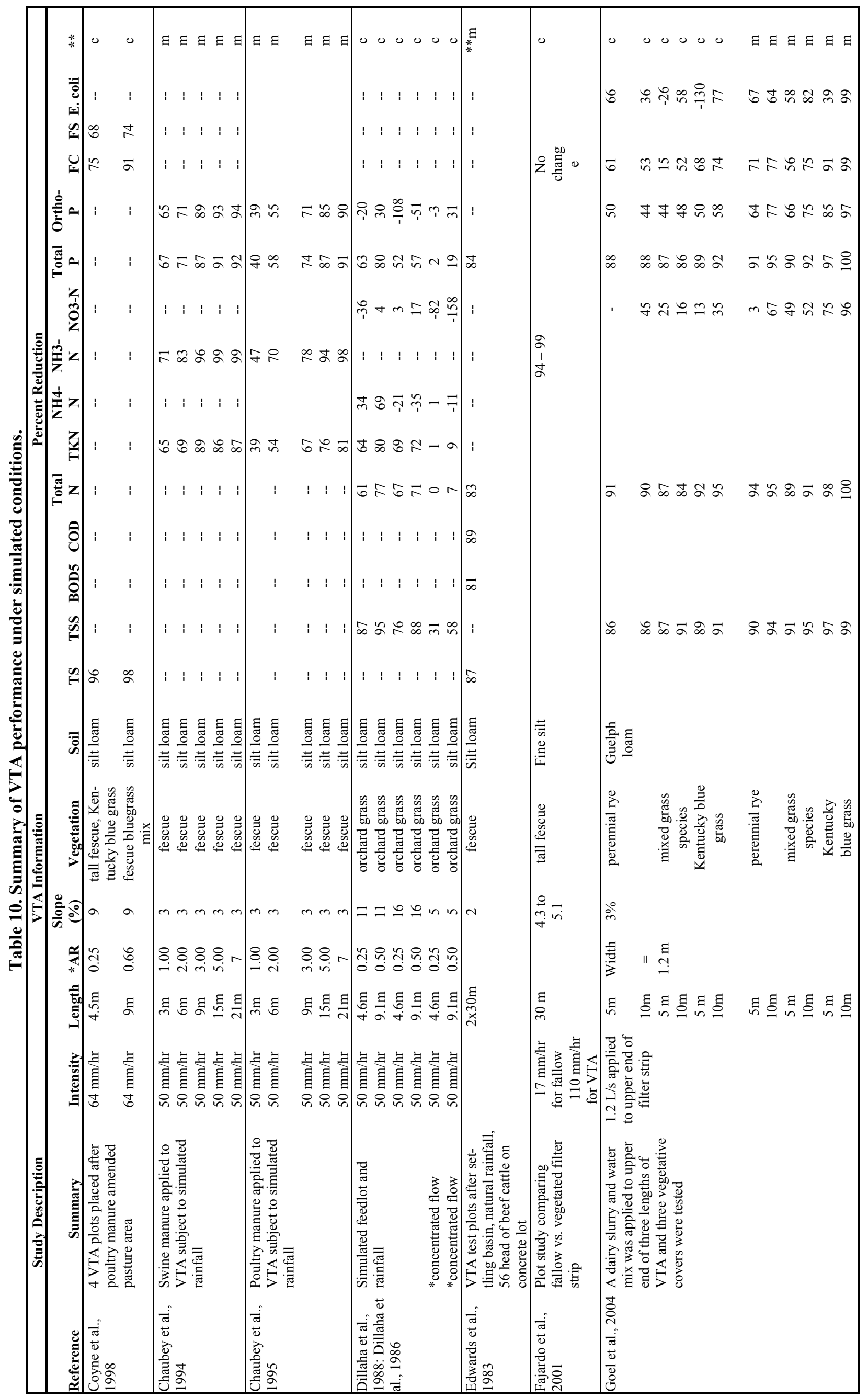




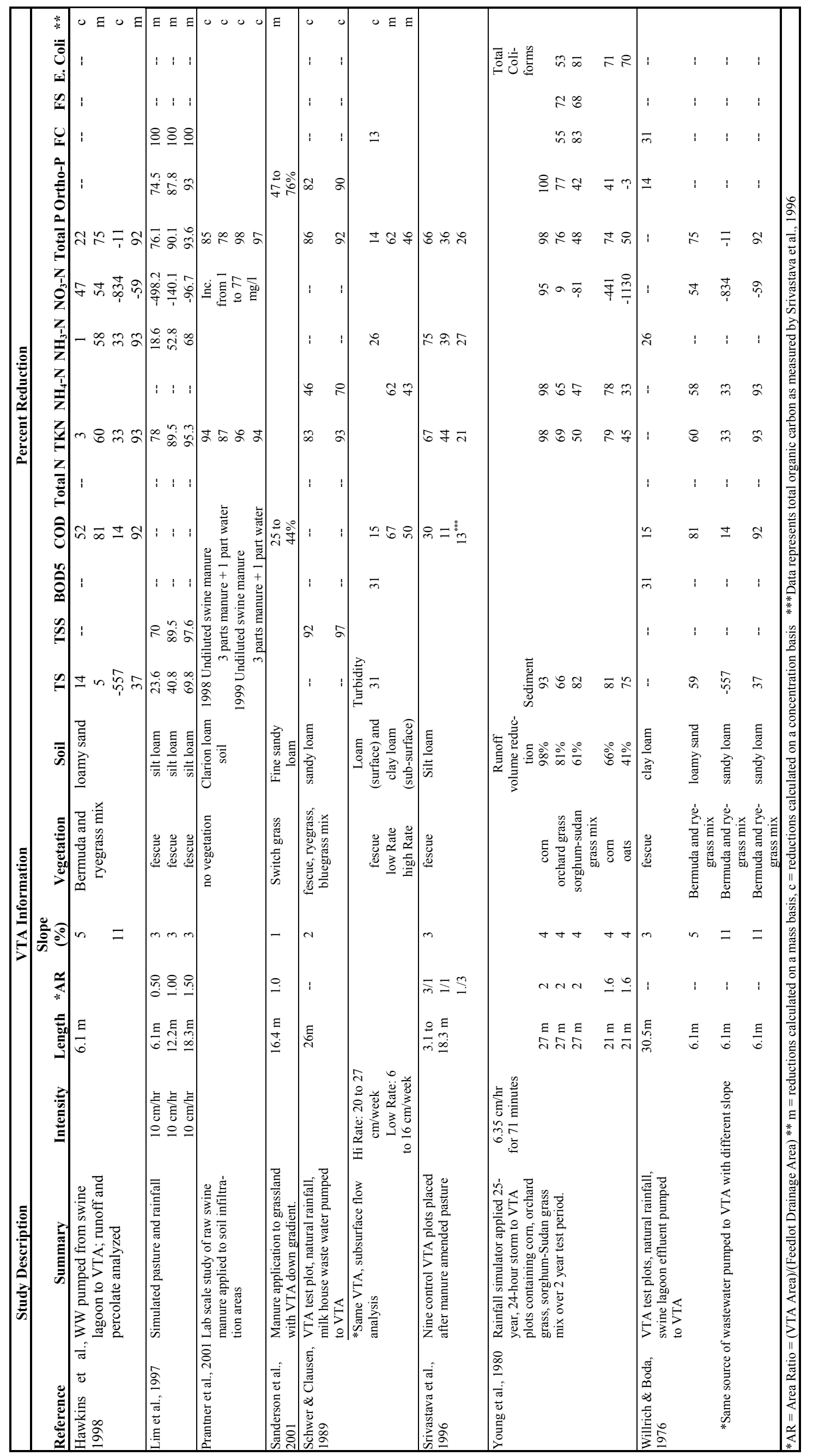


Table 11. Summary of performance observations for VTA for past research and field demonstration projects.

\begin{tabular}{|c|c|c|}
\hline Reference & Type of System & $\begin{array}{l}\text { Performance Observations (in addition to \% reductions } \\
\text { reported in Tables } 9 \text { and 10) }\end{array}$ \\
\hline $\begin{array}{l}\text { Barker and } \\
\text { Young, } 1984\end{array}$ & $\begin{array}{l}\text { Milking center wastewater } \\
\text { and open lot runoff from a } \\
54 \text { cow dairy was directed } \\
\text { to settling basin and VTA. } \\
\text { Four earthen berms located } \\
\text { at } 30 \text { ' intervals were de- } \\
\text { signed to create a cascading } \\
\text { type system. System was } \\
\text { monitored over two years. }\end{array}$ & $\begin{array}{l}\text { - Effluent leaving the VTA effluent was only } 5 \% \text { of VTA influ- } \\
\text { ent volume resulting is high pollutant mass reductions. } \\
\text { - Increased soil nitrates were observed in deep soil samples in } \\
\text { sections prior to first two berms. Increased soil P levels were } \\
\text { also observed ahead of first two berms. No other soil samples } \\
\text { showed increases. } \\
\text { - Soluble salt concentration showed increases in all soil samples } \\
\text { ahead of first two berms. Total cations remained relatively } \\
\text { constant with exception of shallow soil samples taken ahead of } \\
\text { first berm. } \\
\text {-VTA distribution pipe at upper end of field with four separate } \\
\text { outlets produced channel flow concerns. Increasing number of } \\
\text { outlets to seven appeared to reduce channel flow concerns. }\end{array}$ \\
\hline $\begin{array}{l}\text { Coyne et al., } \\
1998\end{array}$ & $\begin{array}{l}\text { Controlled replicated re- } \\
\text { search trials were con- } \\
\text { ducted on VTA of } 4.5 \text { and } \\
9.0 \mathrm{~m} \text { in length below a } \\
\text { simulated pasture area with } \\
\text { poultry manure added. A } \\
64 \mathrm{~mm} / \text { hour rainfall was } \\
\text { applied. }\end{array}$ & $\begin{array}{l}-85 \text { and } 76 \% \text { of total water runoff infiltrated into the } 9.0 \text { and } 4.5 \\
\text { m VFA plots, respectively. } \\
\text { - The } 4.5 \mathrm{~m} \text { VTA trapped most of the sediment in runoff. } \\
\text { - VTA of this length trapped most of the fecal bacteria that } \\
\text { moved onto the site. However, the concentration of fecal bacte- } \\
\text { ria in runoff remained high and exceeded water quality stan- } \\
\text { dards. }\end{array}$ \\
\hline $\begin{array}{l}\text { Chaubey et } \\
\text { al., } 1995\end{array}$ & $\begin{array}{l}\text { Poultry manure applied to } \\
\text { established grass area with } \\
\text { VTA located below area of } \\
\text { land application. Site is } \\
\text { subject to simulated rainfall }\end{array}$ & $\begin{array}{l}\text { - First order linear regression describes reduction in mass trans- } \\
\text { port of litter constituents with VTA length. } \\
\text { - Removal of contaminants in VTA increased for lengths up to } \\
\text { 15.2 meters (ammonia and dissolved phosphorus), } 9.2 \mathrm{~m} \text { (total } \\
\text { Kjeldahl nitrogen and total phosphorus), and } 3.1 \mathrm{~m} \text { (total sus- } \\
\text { pended solids and chemical oxygen demand). } \\
\text { - VTA holds promise for improving quality of runoff from land } \\
\text { application sites treated with poultry litter. }\end{array}$ \\
\hline $\begin{array}{l}\text { Dickey and } \\
\text { Vanderholm } \\
\text { 1981a,b; Van- } \\
\text { derholm and } \\
\text { Dickey, } 1980\end{array}$ & $\begin{array}{l}\text { Papers review design and } \\
\text { performance of four VTA, } \\
\text { two functioning as overland } \\
\text { flow ( } 100 \text { cow dairy and } \\
450 \text { beef feedlot) and addi- } \\
\text { tional two as channelized } \\
\text { flow ( } 500 \text {-head beef feedlot } \\
\text { and } 480 \text {-head swine opera- } \\
\text { tion) }\end{array}$ & $\begin{array}{l}\text { - VTA reduces nutrients, solids and organic matter from feedlot } \\
\text { runoff by over } 80 \% \text { on a concentration basis and } 95 \% \text { on a } \\
\text { weight basis. } \\
\text { - Additional removals are impractical due to quality of runoff } \\
\text { approaching that of agricultural land that is not exposed to } \\
\text { feedlot runoff. Discharge did not meet stream quality stan- } \\
\text { dards. } \\
\text { - Fecal coliform levels from the VTA with feedlot runoff addi- } \\
\text { tion were one log higher than runoff from a control VTA with } \\
\text { no manure addition. Both were high in relation to stream stan- } \\
\text { dards. } \\
\text { - Most runoff events infiltrated completely, resulting in no dis- } \\
\text { charge. Sizing procedures used for project resulted in runoff } \\
\text { only during large precipitation events and high stream flows. }\end{array}$ \\
\hline $\begin{array}{l}\text { Dillaha et al., } \\
\text { 1988; Dillaha } \\
\text { et al., } 1986\end{array}$ & $\begin{array}{l}\text { Controlled replicated re- } \\
\text { search trials were con- } \\
\text { ducted on VTA of } 4.6 \text { and } \\
9.1 \mathrm{~m} \text { in length below a } \\
\text { simulated dairy open lot of } \\
18.3 \text { meters on a silt loam } \\
\text { soil. A } 50 \mathrm{~mm} / \text { hour rainfall } \\
\text { was applied for two hours } \\
\text { on soils described as "dry", } \\
\text { "wet" and "very wet." }\end{array}$ & $\begin{array}{l}\text {-VTA are effective for removal of sediment and suspended sol- } \\
\text { ids with filters of } 9.1 \mathrm{~m} \text { or less if flow is shallow and uniform. } \\
\text { - Some decline in effectiveness is noted with time as sediment } \\
\text { accumulates. } \\
\text { - Total N and P are not removed as effectively as sediment for } \\
\text { the lengths tested. } \\
\text {-VTA lengths used in this research were not effective in remov- } \\
\text { ing soluble N and P. Soluble P was often higher in outflow } \\
\text { than inflow, presumably due to release of P previously trapped } \\
\text { in the VTA. } \\
\text {-VTA with concentrated flow were significantly less effective } \\
\text { than were uniform flow plots. }\end{array}$ \\
\hline
\end{tabular}


Table 11 (continued). Summary of performance observations for VTA for past research and field demonstration projects.

\begin{tabular}{|c|c|c|}
\hline Reference & Type of System & $\begin{array}{l}\text { Performance Observations (in addition to \% reductions } \\
\text { reported in Tables } 9 \text { and 10). }\end{array}$ \\
\hline $\begin{array}{l}\text { Edwards } \\
\text { et al., } 1983\end{array}$ & $\begin{array}{l}\text { VTA test plots after settling } \\
\text { basin, natural rainfall, } 56 \\
\text { head of beef cattle on con- } \\
\text { crete lot. Two grass filter } \\
\text { cells were used in series, } \\
\text { each representing approxi- } \\
\text { mately } 50 \% \text { of the concrete } \\
\text { lot area. }\end{array}$ & $\begin{array}{l}\text { - Settling basin and filter strips reduced contaminant mass trans- } \\
\text { port by } 81 \text { to } 89 \% \text {. } \\
\text { - The settling basin was more effective in large storm events. } \\
\text { - The grass filter strip was more effective when the basin was } \\
\text { slowly drained one day following a storm event. }\end{array}$ \\
\hline $\begin{array}{l}\text { Edwards } \\
\text { et al., } 1986 \\
\text { Fausey } \\
\text { et al., } 1988\end{array}$ & $\begin{array}{l}\text { VIB used with } 56 \text { head of } \\
\text { beef cattle on concrete lot. } \\
\text { VIB was preceded by solids } \\
\text { settling basin. }\end{array}$ & $\begin{array}{l}\text { - Infiltration basin approach eliminated all overland flow runoff } \\
\text { to receiving stream. } \\
\text {-Infiltration basin produced greater nutrient transport reduction } \\
\text { than a } 33 \mathrm{~m} \text { grass filter strip but was less effective than a } 66 \mathrm{~m} \\
\text { grass filter strip. } \\
\text { - Reed canary grass thrived in the infiltration basin. } \\
\text { - Drain tile placed across the slope in the infiltration basin pro- } \\
\text { duced greater discharge volumes and greater pollutant trans- } \\
\text { port from the drain tiles than a single drain tile placed parallel } \\
\text { with the slope of the infiltration basin. }\end{array}$ \\
\hline $\begin{array}{l}\text { Fajardo } \\
\text { et al., } 2001\end{array}$ & $\begin{array}{l}\text { VTA and fallow plots are } \\
\text { placed below area of ma- } \\
\text { nure application. Sufficient } \\
\text { simulated rainfall was ap- } \\
\text { plied to achieve one-hour } \\
\text { runoff event. Much greater } \\
\text { volumes were applied to } \\
\text { VTA plots. }\end{array}$ & $\begin{array}{l}\text { - Bacterial contamination in runoff water was not reduced when } \\
\text { comparing tall fescue and fallow filter strips. Presence of bac- } \\
\text { terial organisms on the soil surface is ubiquitous. Manure addi- } \\
\text { tion did not significantly impact source of bacterial organisms. } \\
\text { - Dilution due to substantially greater water application in VTA } \\
\text { to achieve similar runoff many also be partial explanation for } \\
\text { reduced nitrates and unchanged coliform concentration. (author } \\
\text { note: all comparisons are based only on concentration.) }\end{array}$ \\
\hline $\begin{array}{l}\text { Harner and } \\
\text { Kalita, } \\
1999\end{array}$ & $\begin{array}{l}\text { VTA established on sev- } \\
\text { eral open lot beef systems } \\
\text { in three watersheds, three } \\
\text { of which were monitored } \\
\text { for performance. }\end{array}$ & $\begin{array}{l}\text {-VTA effectively reduces nutrient, sediment, and bacteria } \\
\text { from open lot livestock systems. } \\
\text { - Quality of vegetation impacts nutrient uptake capacity of } \\
\text { VTA. }\end{array}$ \\
\hline $\begin{array}{l}\text { Hawkins } \\
\text { et al., } 1998\end{array}$ & $\begin{array}{l}\text { Effluent pumped from } \\
\text { swine lagoon to VTA; } \\
\text { runoff and percolate ana- } \\
\text { lyzed }\end{array}$ & $\begin{array}{l}\text { - Significant nitrification occurred on the steeper slope and } \\
\text { elevated soil nitrate levels were a concern. }\end{array}$ \\
\hline $\begin{array}{l}\text { Hubbard } \\
\text { et al., } \\
1994 ; \\
\text { Hubbard } \\
\text { et al., } 1999\end{array}$ & $\begin{array}{l}\text { Pre-treated swine lagoon } \\
\text { effluent was applied at a } \\
\text { rate of } 450 \text { and } \\
900 \mathrm{~kg} / \mathrm{ha} / \mathrm{yr} \text { to three VTA } \\
\text { consisting of 1) } 10-\mathrm{m} \text { wide } \\
\text { grass (Bermuda and tall } \\
\text { fescue) followed by } 20-\mathrm{m} \\
\text { riparian zones, 2)10-m } \\
\text { grass and } 20-\mathrm{m} \text { maiden- } \\
\text { cane zones and 3) } 20-\mathrm{m} \\
\text { grass and } 10-\mathrm{m} \text { riparian } \\
\text { zones. } \\
\text { Pre-treated swine lagoon } \\
\text { effluent was applied at a } \\
\text { rate of } 800 \mathrm{~kg} \text { N and } \\
150 \mathrm{~kg} \text { P per ha per year to } \\
\text { six different wetland and } \\
\text { riparian plant species to } \\
\text { evaluate plant response. }\end{array}$ & $\begin{array}{l}\text { - Intense monitoring of nitrogen in soil, ground water, and } \\
\text { surface water runoff was reported for a nine month period } \\
\text { with no differences in treatments observed at this time. } \\
\text { - All three treatments sere effectively filtering } \mathrm{N} \text { from applied } \\
\text { swine manure at both rates. } \\
\text { - Significant reductions in ammonium in surface runoff were } \\
\text { noted with down gradient distance from point of swine ma- } \\
\text { nure application. Nitrate concentration increased from less } \\
\text { than } 1 \mathrm{mg} / \text { liter to between } 1 \text { and } 15 \mathrm{mg} / \text { liter. } \\
\text { - All species responded well to swine effluent application with } \\
\text { buttonbush and saltmeadow cordgrass showing the greatest } \\
\text { growth response. }\end{array}$ \\
\hline
\end{tabular}


Table 11 (continued). Summary of performance observations for VTA for past research and field demonstration projects.

\begin{tabular}{|c|c|c|}
\hline Reference & Type of System & $\begin{array}{l}\text { Performance Observations (in addition to \% reduc- } \\
\text { tions reported in Tables } 9 \text { and } 10 \text { ). }\end{array}$ \\
\hline $\begin{array}{l}\text { Lim et al., } \\
1998\end{array}$ & $\begin{array}{l}\text { Cattle manure was ap- } \\
\text { plied to upper } 12.2 \mathrm{~m} \text { of } \\
\text { grassed plots. Runoff was } \\
\text { collected at } 0,6.1,12.2, \\
\text { and } 18.3 \text { meters below } \\
\text { area of manure applica- } \\
\text { tion for simulated rainfall } \\
\text { of } 100 \mathrm{~mm} / \mathrm{hr} \text {. }\end{array}$ & $\begin{array}{l}\text { - No concentration reductions were observed after first } 6.1 \\
\text { meters. } \\
\text { - Concentration and mass transport reductions of the ana- } \\
\text { lyzed parameters followed a first-order exponential reduc- } \\
\text { tion relationship with length of VTA. }\end{array}$ \\
\hline $\begin{array}{l}\text { Lorimor et al., } \\
2003\end{array}$ & $\begin{array}{l}\text { Runoff from } 380 \text {-head } \\
\text { concrete feedlot passes } \\
\text { through settling channel } \\
\left(1^{\text {st }} \text { stage }\right) \text {, infiltration } \\
\text { basin }\left(2^{\text {nd }} \text { stage }\right) \text {, and wet- } \\
\text { lands }\left(3^{\text {rd }} \text { stage }\right) \text {. }\end{array}$ & $\begin{array}{l}\text { - Overall mass flow reductions have been between } 86 \text { and } \\
98 \% \text { for this system, with most significant reductions due } \\
\text { to VIB. } \\
\text { - After five years of use, soil phosphorus levels within the } \\
\text { infiltration basin have not shown signs of buildup. } \\
\text { - Although the flow out of the infiltration basin is not con- } \\
\text { tinuous, it has a substantially lower peak and extended pe- } \\
\text { riod of flow as compared to the runoff flow from the feed- } \\
\text { lot. The infiltration basin also stores significant quantities } \\
\text { of water subsequently used by plant growth thus reducing } \\
\text { total volume. This change in flow pattern is beneficial to } \\
\text { secondary treatment systems. }\end{array}$ \\
\hline $\begin{array}{l}\text { Mankin and } \\
\text { Okoren, } 2003\end{array}$ & $\begin{array}{l}300 \text {-head heifer feedlot } \\
\text { with runoff directed to } \\
\text { settling basin }\left(1^{\text {st }} \text { stage }\right) \\
\text { and VTA }\left(2^{\text {nd }} \text { stage }\right) \text {. }\end{array}$ & $\begin{array}{l}\text { - Mass reduction of constituents occurred in first } 30 \mathrm{~m} \text {. Lit- } \\
\text { tle or no reduction occurred in last } 120 \mathrm{~m} \text {. } \\
\text { - Fecal coliform concentration was reduced below accepted } \\
\text { water quality standards.: }\end{array}$ \\
\hline $\begin{array}{l}\text { Nienaber et al., } \\
1974\end{array}$ & $\begin{array}{l}\text { Settling basin, holding } \\
\text { pond, sprinkler irrigation } \\
\text { on grassed treatment area. } \\
\text { Fresh water application } \\
\text { compared with beef feed- } \\
\text { lot runoff. }\end{array}$ & $\begin{array}{l}\text { - Application rates of } 64 \mathrm{~cm}(25 \text { inches) in } 1971 \text { and } 91 \mathrm{~cm} \\
\text { (36 inches) in } 1972 \text { did not result in runoff (applied mid } \\
\text { spring through late fall) or accumulation of nitrogen, } \\
\text { phosphorus, or chlorides. }\end{array}$ \\
\hline $\begin{array}{l}\text { Paterson et al., } \\
1980\end{array}$ & $\begin{array}{l}\text { Milking center waste and } \\
\text { barnyard runoff from } 70 \\
\text { cow dairy was directed } \\
\text { through settling basin }\left(1^{\text {st }}\right. \\
\text { stage), holding tank with } \\
\text { lift pump, and VTA ( } 2^{\text {nd }} \\
\text { stage). }\end{array}$ & $\begin{array}{l}\text { - Four pollutants (BOD, NH4, PO4, and suspended solids) } \\
\text { decreased in concentration by passing though VTA. } \\
\text { - Four pollutants were reduced by } 97 \% \text { or more in perched } \\
\text { ground water while nitrate increased. } \\
\text { - Nitrate increased during passage through VTA except } \\
\text { during winter where nitrate was reduced in concentration. }\end{array}$ \\
\hline $\begin{array}{l}\text { Prantner et al., } \\
2001\end{array}$ & $\begin{array}{l}\text { Undiluted swine manure, } \\
3 \text { to } 1 \text { swine manure and } \\
\text { water, and water applied } \\
\text { to buried containers with } \\
\text { grass (first stage) fol- } \\
\text { lowed by wetland plants } \\
\left(2^{\text {nd }} \text { stage). Sufficient }\right. \\
\text { manure or water volume } \\
\text { applied at } 2 \text { week inter- } \\
\text { vals to saturate soil col- } \\
\text { umn. }\end{array}$ & $\begin{array}{l}\text { - Systems were designed to encourage nitrification fol- } \\
\text { lowed by denitrification processes and soil absorption and } \\
\text { settling of phosphorus. The 2-year study produced } 99.5 \\
\text { and } 99.9 \% \text { reduction in ammonium-N, } 98.5 \text { and } 99.8 \% \\
\text { reduction in total P and ending nitrate concentrations of } \\
0.2 \mathrm{mg} / 1 \text { (1998) and } 7 \text { to } 9 \mathrm{mg} / 1 \text { (1999). Similar percent- } \\
\text { age of reduction of ammonium and phosphorus were ob- } \\
\text { served in the infiltration and wetland zones. Soil P accu- } \\
\text { mulation was a concern but not observed in } 2 \text { year study. }\end{array}$ \\
\hline
\end{tabular}


Table 11 (continued). Summary of performance observations for VTA for past research and field demonstration projects.

\begin{tabular}{|c|c|c|}
\hline Reference & Type of System & $\begin{array}{l}\text { Performance Observations (in addition to \% reduc- } \\
\text { tions reported in Tables } 9 \text { and 10). }\end{array}$ \\
\hline $\begin{array}{l}\text { Sanderson } \\
\text { et al., } 2001\end{array}$ & $\begin{array}{l}\text { Solid dairy manure } \\
\text { (1995) and dairy lagoon } \\
\text { effluent (1996 and 1997) } \\
\text { was applied at rates rang- } \\
\text { ing from } 0 \text { to } 600 \mathrm{~kg} \mathrm{~N} / \mathrm{ha} \\
\text { in a replicate plot design. } \\
\text { Manure was applied to a } \\
\text { switch grass area with a } \\
\text { VTA consisting of switch } \\
\text { grass below the manured } \\
\text { plots. }\end{array}$ & $\begin{array}{l}\text {-VTA effectively reduced total reactive } \mathrm{P} \text { and COD con- } \\
\text { centrations in surface runoff. } \\
\text { - Runoff concentration of N, P, and COD decreased as } \\
\text { greater time lapsed between manure application and pre- } \\
\text { cipitation event. To minimize } \mathrm{N} \text { and COD runoff concen- } \\
\text { trations, } 3 \text { to } 4 \text { days was suggested. To minimize } \mathrm{P} \text { con- } \\
\text { centrations, then } 1 \text { day was necessary. }\end{array}$ \\
\hline $\begin{array}{l}\text { Scheilinger } \\
\text { and Clausen, } \\
1992\end{array}$ & $\begin{array}{l}\text { Concrete dairy barnyard } \\
\text { runoff flows through a } \\
\text { detention pond and into a } \\
22.9 \mathrm{~m} \text { by } 7.6 \mathrm{~m} \text { VTA } \\
\text { with } 2 \% \text { slope. }\end{array}$ & $\begin{array}{l}\text { - } 65 \% \text { of barnyard runoff exited from VTA. Retention of } \\
\text { solids, N, P, K, and bacteria was considered poor. } \\
\text { - Average hydraulic retention time of } 15 \text { minutes was ob- } \\
\text { served. } \\
\text { - Inadequate detention time and excessive hydraulic deten- } \\
\text { tion times were identified as reasons for poor perform- } \\
\text { ance. }\end{array}$ \\
\hline $\begin{array}{l}\text { Schmitt et al., } \\
1999\end{array}$ & $\begin{array}{l}\text { Alternative lengths of } \\
\text { VTA and types of vegeta- } \\
\text { tion were evaluated for } \\
\text { agricultural field runoff. }\end{array}$ & $\begin{array}{l}\text {-VTA performance is strongly dependent upon type of } \\
\text { contaminants. VTA are most effective for sediment re- } \\
\text { lated contaminants and least effective for dissolved con- } \\
\text { taminants. } \\
\text { - Doubling filter strip from } 7.5 \text { to } 15 \mathrm{~m} \text { does not improve } \\
\text { sediment settling, increases infiltration, and increases di- } \\
\text { lution of runoff. } \\
\text { - Incorporating trees and shrubs into the lower half of filter } \\
\text { strips does not affect performance. } \\
\text { - Contour sorghum strips of equal width are not as effective } \\
\text { at reducing contaminants as perennial vegetation. }\end{array}$ \\
\hline $\begin{array}{l}\text { Schwer and } \\
\text { Clausen, } 1989\end{array}$ & $\begin{array}{l}\text { VTA was designed to } \\
\text { treat milk house wastewa- } \\
\text { ter on a Vermont Dairy. }\end{array}$ & $\begin{array}{l}\text { - Retention was greatest during the growing season and } \\
\text { least during snow melt. } \\
\text { - Retention of N \& P in harvested crops accounted repre- } \\
\text { sented only a small portion of input nutrients. }\end{array}$ \\
\hline $\begin{array}{l}\text { Srivastava } \\
\text { et al., } 1996\end{array}$ & $\begin{array}{l}\text { Nine control VTA plots, } \\
\text { ranging from } 3 \text { to } 18.3 \mathrm{~m}, \\
\text { were placed after poultry } \\
\text { manure amended pasture }\end{array}$ & $\begin{array}{l}\text {-Pollutant concentration of water exiting litter treated areas } \\
\text { is not dependent on litter treated length, suggested rapid } \\
\text { equilibrium being reached. } \\
\text {-Pollutant concentrations decreased with increasing VTA } \\
\text { length for all pollutants. } \\
\text { - Mass transport was not affected by VTA length with large } \\
\text { portion of the mass removal occurring within the first } 3 \mathrm{~m} \\
\text { of VTA. }\end{array}$ \\
\hline
\end{tabular}


Table 11 (continued). Summary of performance observations for VTA for past research and field demonstration projects.

\begin{tabular}{|c|c|c|}
\hline Reference & Type of System & $\begin{array}{l}\text { Performance Observations (in addition to \% reduc- } \\
\text { tions reported in Tables } 9 \text { and } 10 \text { ). }\end{array}$ \\
\hline $\begin{array}{l}\text { Willrich and } \\
\text { Boda, } 1976\end{array}$ & $\begin{array}{l}\text { Anaerobic lagoon swine } \\
\text { effluent is applied to up- } \\
\text { per end of six plots. }\end{array}$ & $\begin{array}{l}\text { - Overland flow treatment of swine lagoon effluent caused } \\
\text { significant concentration attenuations and mass reductions } \\
\text { of its polluting properties. } \\
\text { - BOD and turbidity removal became effective with time } \\
\text { whereas treatment effectiveness for COD, phosphorus, sa- } \\
\text { linity and ammonia decreased with time. } \\
\text { - Changes in application rate impacted runoff volumes but } \\
\text { did not significantly change concentration of most con- } \\
\text { taminants. } \\
\text { - Significantly greater attenuation occurred during cool, wet } \\
\text { months for turbidity and fecal coliform and during warm, } \\
\text { dry months for phosphorus. Nitrification was also greater } \\
\text { during warn, dry months. }\end{array}$ \\
\hline $\begin{array}{l}\text { Woodbury } \\
\text { et al., 2002, } \\
\text { 2003a, 2003b }\end{array}$ & $\begin{array}{l}\text { Runoff from eight open } \\
\text { lot beef cattle pens (about } \\
600 \text { cattle) moved from } \\
\text { the pens through a grass } \\
\text { approach, settling basin } \\
\text { (created by a } 300 \mathrm{~m} \text { long } \\
\text { terrace below the pens), } \\
\text { and a } 6 \text { ha VTA ). }\end{array}$ & $\begin{array}{l}\text { - The settling basin removed } 80,67,59 \text {, and } 47 \% \text { of the to- } \\
\text { tal suspended solids, volatile suspended solids, chemical } \\
\text { oxygen demand, and total nitrogen. } \\
\text { - Distribution of settling basin water to a VTA was not uni- } \\
\text { form resulting in soil nitrate accumulation in upper } 30 \mathrm{~cm} \\
\text { ( } 1 \text { foot). } \\
\text { - No water was measured exiting the VTA below the root } \\
\text { zone or at the down gradient end of the VTA over a three- } \\
\text { year period suggesting hay crop utilization of all applied } \\
\text { water. } \\
\text { - Mass nitrogen removal by harvesting exceeded mass ni- } \\
\text { trogen addition with feedlot runoff. } \\
\text { - Migration of nitrate below the settling basin is a problem, } \\
\text { possibly exacerbated by solids removal and basin clean- } \\
\text { ing. }\end{array}$ \\
\hline $\begin{array}{l}\text { Young et al., } \\
1980\end{array}$ & $\begin{array}{l}\text { Rainfall simulator applied } \\
25 \text {-year, 24-hour storm to } \\
\text { VTA plots containing } \\
\text { corn, orchard grass, sor- } \\
\text { ghum-Sudan grass mix, } \\
\text { oats over } 2 \text { year test pe- } \\
\text { riod. }\end{array}$ & $\begin{array}{l}\text { - Significant reductions on nitrogen forms (with exception } \\
\text { of nitrate), phosphorus, and microorganisms were ob- } \\
\text { served for } 36 \text { m VTA. } \\
\text { - Nonstructural control practices are a promising alternative } \\
\text { method for controlling feedlot runoff. }\end{array}$ \\
\hline $\begin{array}{l}\text { Younos et al., } \\
1998\end{array}$ & $\begin{array}{l}18 \text { m wide VTA placed } \\
\text { down gradient from open } \\
\text { lot for } 60 \text {-head dairy. }\end{array}$ & $\begin{array}{l}\text { - Stream loads for total runoff, orthophosphate and dis- } \\
\text { solved phosphorus, total phosphorus, and total nitrogen } \\
\text { were lower after VTA installation as compared to a pre- } \\
\text { VTA installation. However, due to the relatively short } \\
\text { monitoring (6 months prior and after installation), differ- } \\
\text { ences were statistically inconclusive. } \\
\text { - Although the water quality upstream of the sacrifice lot is } \\
\text { already degraded, the installation of the VTA may prevent } \\
\text { a further degradation of the water quality downstream of } \\
\text { the sacrifice lot. }\end{array}$ \\
\hline
\end{tabular}




\section{VTA DESIGN}

The literature provided illustrations of a number of critical design considerations for VTAs (Table 12). Based upon this literature, there are several design considerations that are generally accepted for VTAs:

- A need exists for some degree of pretreatment. Solids settling is commonly used with VTAs to minimize solids accumulation at the front end of a VTA. This pre-treatment minimizes vegetation damage and reduces the potential for channel flow paths developing where runoff first enters the VTA.

- Uniform sheet flow of liquid is essential for optimum VTA performance. Design of inlets and headlands is critical to initiating sheet flow. Field management is critical to minimizing concentrated flow. Even with the best inlet design and management, concentrated flow is likely to occur within a VTA and may requiring additional structures to redistribute flow.

- For VTS on CAFOs, minimizing potential for discharge will be critical for achieving equal or better performance than baseline technologies. Combinations of treatment components into systems, attention to sizing, and modification of hydrograph of flow into a VTA are important considerations for minimizing discharge potential.

- Siting criteria is critical to the appropriate application of VTAs. Iowa Department of Natural Resources has established nine evaluation criteria used to initially judge a site including available area, soil permeability, depth to water table, subsoil and geology, slope, spreaders for uniform distribution, berming for inflow water protection, flooding potential, and proximity to waters of the state (Iowa Department of Natural Resources, 2004).

Multiple approaches have been suggested for VTA sizing:

- Dickey and Vanderholm (1981a) recommended a minimum VTA width of $61 \mathrm{~m}$ (200 ft) and a length adequate to completely infiltrate the feedlot runoff and rainfall from a 1-yr, 2-hr storm. They calculated minimum flow lengths to provide 2-hour contact times. Based on their model, minimum lengths varied from $91 \mathrm{~m}$ (300 feet) for a $0.5 \%$ slope up to $262 \mathrm{~m}$ (860 feet) for a $4 \%$ slope. They also recommended that an infiltration area be designed to allow infiltration for all runoff from a 1-year, 2-hour storm.

- Nienaber et al. (1974) suggested a disposal area of one-half hectare per hectare of feed lot is needed. Data in Figure 4 suggest that a ratio of 1 to 1 (disposal to feedlot area) or greater is necessary to achieve peak performance. Lorimor et al. (2003) has achieved high contaminant removal rates with a ratio of 1 to 6 (infiltration basin to feedlot area) for a bermed infiltration area that allows discharges only through subsurface drain tiles.

- A design procedure was developed by NRCS in Pennsylvania suggesting that the VTA be designed for the peak discharge resulting from a 2-year, 24-hour storm event at a maximum flow depth of $1.3 \mathrm{~cm}$ with a minimum flow through time of 15 minutes (Murphy and Bogovich, 2001). A design procedure based upon a sheet flow equation was proposed:

$$
\mathrm{T}=0.07(\mathrm{n} \mathrm{L})^{0.8} /\left(\mathrm{P}_{2}\right)^{0.5} \mathrm{~s}^{0.4}
$$

where $\mathrm{T}$ represents travel time (hours), $\mathrm{n}$ represents Manning's roughness coefficient ( 0.24 for dense grass), $\mathrm{L}$ equals flow length (feet), $\mathrm{P}_{2}$ equals 2-yr, 24-hour storm, and s equals land slope (ft/ft). Scheilinger and Clausen (1992) used a USDA SCS design standard for Vermont applications and observed poor performance results. Additional design criteria have been assembled by other USDA NRCS state offices including the Montana Supplement to Chapter 10 of the Agricultural Waste Management Field Handbook (Montana NRCS, 2003). All of these practice standards have typically targeted non-CAFO units. For example, the Montana practice standard states that "final designs for feedlots larger than 3 acres (about 600 cattle) should not be designed with the Simplified Method (Montana practice standard).

- Murphy and Harner (2001) suggested sizing a VTA area based upon normal nitrogen runoff balanced against nitrogen removal as harvested hay. Procedures for estimating mass of nitrogen runoff from the feedlot and example design calculations are provided by this resource.

- Black (1984) proposed a design procedure based on a maximum allowable hydraulic load to the filter,

$$
\mathrm{R}_{\mathrm{w}}=\mathrm{P}+(\mathrm{D} / 10)+\mathrm{SR}
$$


In this equation, $\mathrm{R}_{\mathrm{w}}$ represents the maximum allowable wastewater hydraulic load in $\mathrm{cm} / \mathrm{yr}, \mathrm{P}$ is the soil permeability in $\mathrm{cm} / \mathrm{yr}$, D is the soil water deficit in $\mathrm{mm} / \mathrm{yr}$, and SR is the seasonal runoff rate in $\mathrm{cm} / \mathrm{yr}$. After calculating $\mathrm{R}_{\mathrm{w}}$, a required VTA area can be calculated by dividing the total flow expected, which includes wastewater, runoff, and direct precipitation, by $\mathrm{R}_{\mathrm{w}}$.

- Overcash (1981) proposed a design equation based on influent and effluent concentrations,

$$
\mathrm{C}_{\mathrm{X}}=\mathrm{C}_{\mathrm{B}}+\left(\mathrm{C}_{\mathrm{O}}-\mathrm{C}_{\mathrm{B}}\right) \times \mathrm{e}^{\{[1 /(1-\mathrm{D})] \times \ln [1 /(1+\mathrm{K})]\}}
$$

This procedure requires knowledge of the influent contaminant concentrations, $\mathrm{C}_{\mathrm{O}}$, to the VTA. A desired VTA effluent concentration, $C_{X}$, can then be selected. $C_{B}$ represents the background concentration, $\mathrm{D}$ is the ratio of infiltration to runoff, and $\mathrm{K}$ is the ratio of VTA length to waste area length. Once $\mathrm{C}_{\mathrm{X}}, \mathrm{C}_{\mathrm{B}}, \mathrm{C}_{\mathrm{O}}$, and $\mathrm{D}$ have been determined, the equation must be solved for $\mathrm{K}$ to size the filter strip. This calculation should be made for all contaminants of concern, and filter strip length be selected based on the limiting contaminant.

\section{VTA MAINTENANCE}

Several maintenance issues are critical in VTA function (Table 12):

- A good stand of dense vegetation is needed. Dickey and Vanderholm (1981) noted that dormant residues are effective for filtering and settling pollutants. Management practices that contribute to strong fall growth and well-established winter vegetative cover are critical. Regular harvesting (including hay removal), prevention of channel flow, and minimizing solids accumulation in the VTA are of value in achieving dense fall vegetation. Soil testing to determine fertilization will be of value.

- Uniform flow conditions are essential to VTA performance. Minimal animal traffic and limiting of vehicle traffic to dry conditions are critical.

- Prevention of nutrient accumulation in VTA is important. Regular harvesting with crop removal to encourage a balance of nutrients of nutrients is necessary. Animal grazing does not represent an acceptable harvesting option. Regular soil testing for residual soil nitrates and phosphorus is suggested at the upper end of the VTA. Higher nutrient deposition is anticipated in the first few meters of the VTA suggesting a potential for nitrate leaching and increased soil phosphorus.

\section{CONCLUSIONS}

Based upon this review of the literature, the following conclusions are drawn about the application of vegetative treatment areas to runoff from open lot livestock production systems:

- Substantial research (approximately 40 identified field trials and plot studies) provides a basis for understanding the performance of VTS. A superior research knowledge base exists for performance of VTS as compared to baseline systems for CAFO regulation compliance.

- The baseline systems for CAFO regulation compliance perform well in the High Plains regions of the U.S. where significant moisture deficits (rainfall minus evaporation) exist. However, the performance of these baseline technologies drops substantially for decreasing moisture deficits found in the central and eastern Corn Belt states. These trends have been established through computer modeling processes but not confirmed with in-field performance measurements.

- The existing research targeting VTS is confined to non-CAFO applications, likely due to past regulatory limits. Unique challenges exist in adapting these results and recommendations to CAFO applications.

- The pollutant reduction resulting from a VTS is based upon two primary mechanisms: (1) sedimentation, typically occurring within the first few meters of a VTS, and (2) infiltration of runoff into the soil profile. Systems relying primarily on sedimentation only are unlikely to perform equal or better than baseline technologies. System design based upon sedimentation and infiltration is necessary to achieve a required performance level for CAFO application. 


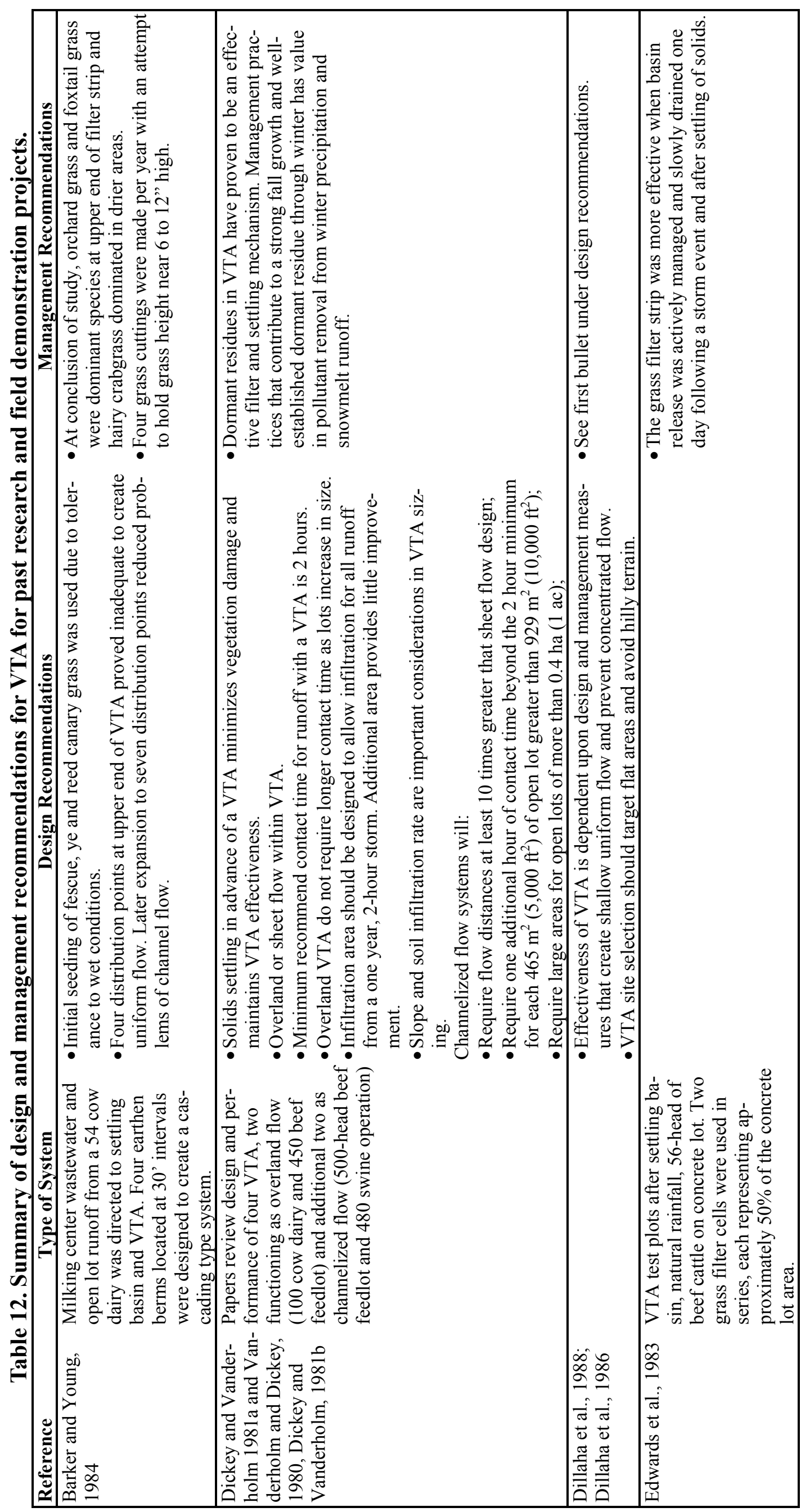




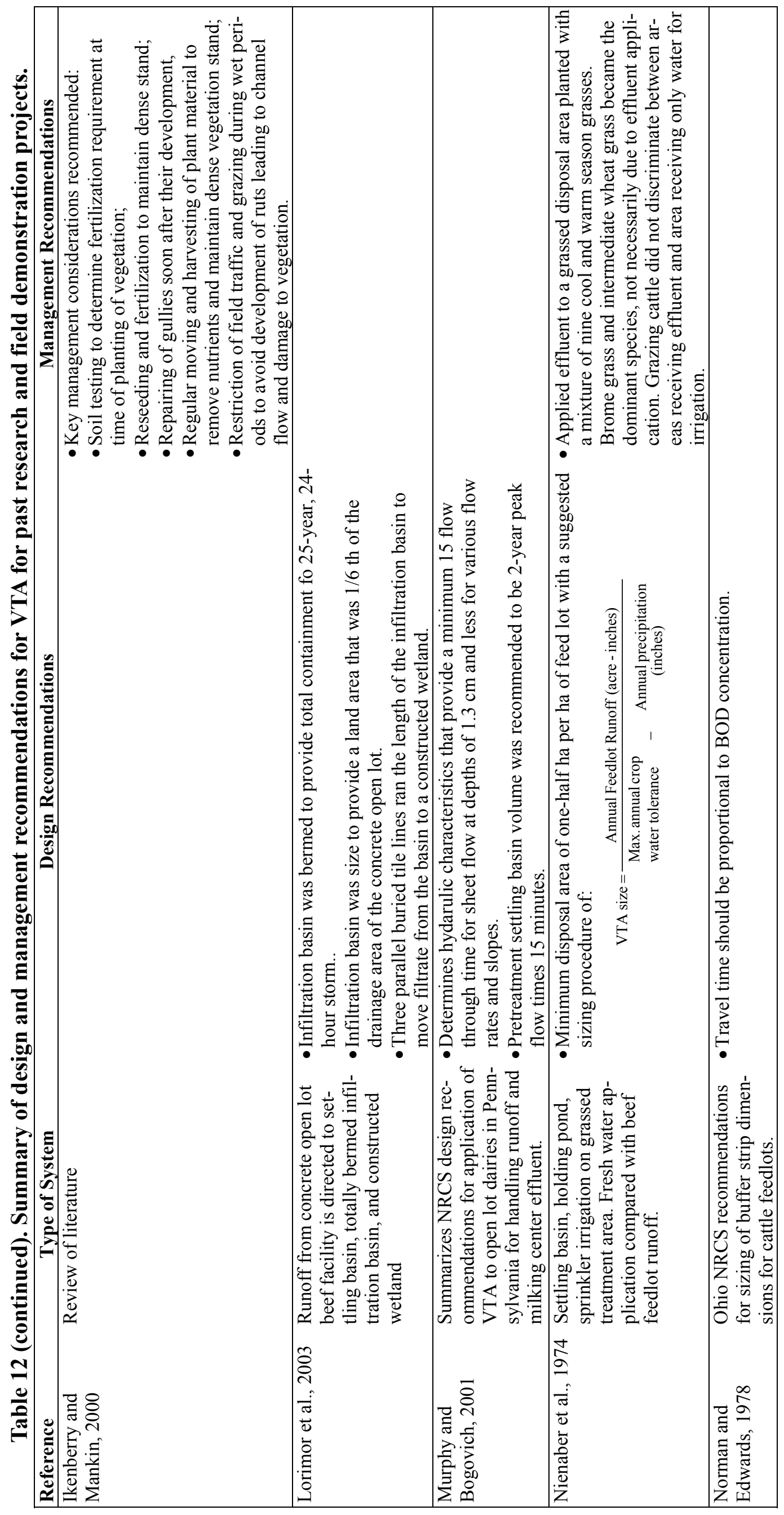




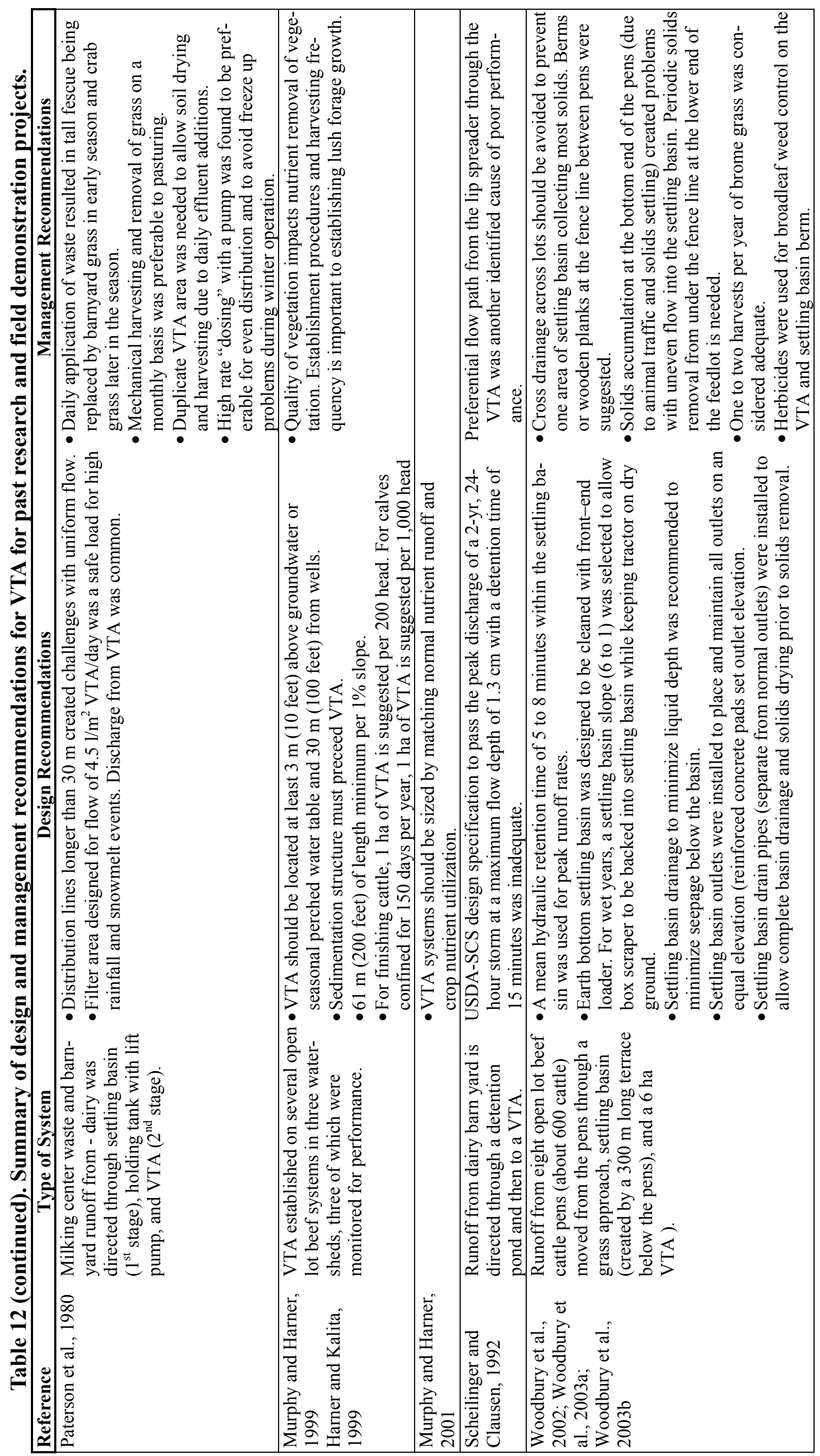




\section{REFERENCES}

Anschutz, J.A., J.K. Koelliker, J.J. Zovne, T.A. Bean, and M.J. Peterson. 1979. Sizing components on open feedlot runoff control systems. Transactions of the ASAE.. 22: 803-808.

Barker, J. C. and B. A. Young. 1984. Evaluation of a vegetative filter for dairy wastewater treatment in southern Appalachia. North Carolina State University research report. Published by US Department of Commerce, National Technical Information Service. 69 pages.

Brach, J. C. 2003. Feedlot runoff control, the Minnesota approach. ASAE Paper Number 032310. 2003 ASAE Annual International Meeting. 6 pages.

Chaubey, I., D.R. Edwards, T.C. Daniel, P.A. Moore and D.J. Nichols. 1994. Effectiveness of vegetative filter strips in retaining surface applied swine manure constituents. Transactions of the ASAE.. 37(3): 845-850.

Chaubey, I., D. R. Edwards, T. C. Daniel, P. A. Moore, Jr. and D. J. Nichols. 1995. Effectiveness Of vegetative filter strips in controlling losses of surface-applied poultry litter constituents. Transactions of the ASAE. 38(6): 1687-1692.

Clark, R. N., C. B. Gilbertson, and H. R. Duke. 1975. Quantity and quality of beef feedyard runoff in the Great Plains. Managing Livestock Wastes, The Proceedings of the 3rd International Symposium on Livestock Wastes. ASAE. St. Joseph, MI. pp.429-431.

Coyne, M. S., R. A. Gilfillen, A. Villalba, Z. Zhang, R. Rhodes, L. Dunn, and R. L. Blevins. 1998. Fecal bacterial trapping by grass filter strips during simulated rain. J. Soil and Water Conservation. 53(2): 140-145.

Culbertson, T. L. and S. L. Hutchinson. 2004. Bioretention cell. Resource: Engineering \& Technology for a Sustainable World. March 2004. ASAE. St. Joseph, MI. pp. 9-10.

Dickey, E.C. and D.H. Vanderholm. 1981a. Performance and design of vegetative filters for feedlot runoff treatment. Livestock Waste: A Renewable Resource. Proc. of the 4th International Symposium on Livestock Wastes, 1980. ASAE. St. Joseph, MI. 49085. pp 257-260.

Dickey, E.C. and D.H. Vanderholm. 1981b. Vegetative filter treatment of livestock feedlot runoff. $J$. Environ. Qual. 10(3): 279-284.

Dillaha, T. A., J. H. Sherrard, D. Lee, S. Mostaghimi, V. O. Shanholtz. 1988. Evaluation of vegetative filter strips as a best management practice for feed lots. J. Water Pollution Control Federation. 60(7): 1231-1238.

Dillaha, T. A., J. H. Sherrard, D. Lee, S. Mostaghimi, V. O. Shanholtz and W. L. Magette. 1986. Use of vegetative filter strips to minimize sediment and phosphorus losses from feedlots: Phase I. Experimental Plot Studies. Virginia Water Resources Research Center, Virginia Polytechnic Institute and State University. Bulletin 151.

Edwards, W.M., L.B. Owens and R.K. White.1983. Managing runoff from a small, paved beef feedlot. J. Environ. Qual. 12(2): 281-286.

Edwards, W.M., L.B. Owens, R.K. White and Fausey, N. R. 1986. Managing feedlot runoff with a settling basin plus tiled infiltration bed. Transactions of the ASAE. 29(1): 243-247.

Erickson, G. and W. Kissinger. 2004. Unpublished runoff data from five years of nutrient balance studies on University of Nebraska beef feedyard. Personal communications, June 1, 2004.

Fajardo, J.J., J.W. Bauder and S.D. Cash. 2001. Managing nitrate and bacteria in runoff from livestock confinement areas with vegetative filter strips. J. Soil and Water Conservation. 56(3): $185-191$.

Fausey, N. R., W. M. Edwards, L.B. Owens and R.K. White. 1988. Subsurface drained infiltration beds for feedlot runoff management. Transactions of the ASAE. 31(1): 98-101.

Federal Register. 2003. 40 CR Parts 9, 122, 123, and 412, National Pollution Discharge Elimination System Regulation and Effluent Limitation Guidelines and Standards for Concentrated Animal Feeding Operations; Final Rule. February 12, 2003. 68(29): 7176-7274.

Fischer, J.R., D.M. Sievers and C.D. Fulhage. 1975. Settling characteristics of swine manure as related to digester loading. In Managing Livestock Wastes. Proceedings of the 3rd International Symposium on Livestock Waste, American Society of Agricultural Engineers, St. Joseph, MI. pp. 456-462. 
Gilbertson, C. B., T. M. McCalla, J. R. Ellis, O. E. Cross, and W. R. Woods. 1970. The effect of animal density and surface slope on unpaved beef feedlots. Nebraska Agr. Exp. Sta. Pub. No. SB508.

Gilbertson, C. B., T. M. McCalla, J. R. Ellis, and W. R. Woods. 1971. Methods of removing settleable solids from outdoor beef cattle feedlot runoff. Transactions of the ASAE. 14(5):899905.

Gilbertson, C. B., J. A. Nienaber, T. M. McCalla, J. R. Ellis, and W. R. Woods. 1972. Beef cattle feedlot runoff, solids transport and settling characteristics. Transactions of the ASAE 15(6):11321134.

Gilbertson, C. B. and J. A. Nienaber. 1973. Beef cattle feedlot runoff-Physical properties. Transactions of the ASAE. 16(5):997-1001.

Gilbertson, C. B. and J. A. Nienaber. 1973. Feedlot runoff control system design and installation A case study: Proceedings, Livestock Waste Management System Design Conference for Consulting and SCS Engr. University of Nebraska. pp. IV 1-IV 16.

Gilbertson, C. B., J. A Nienaber, J. L. Gartung, J. R. Ellis and W. E. Splinter. 1979. Runoff control comparisons for commercial beef cattle feedlots. Transactions of the ASAE. Paper No. 842-847. ASAE, St. Joseph, MI 49085

Gilbertson, C. B., Ellis, J. A Nienaber, T. M. McCalla and T. J. Klopfenstein. 1975. Physical and chemical properties of outdoor beef cattle feedlot runoff. Agricultural Experiment Station, University of Nebraska. 16 pages.

Goel, P. K., R. P. Rudra, B. Gharabaghi, S. Das, N. Gupta. 2004. Pollutants removal by vegetative filter strips planted with different grasses. ASAE paper no 042177. Presented at 2004 International ASAE Meeting, Ottawa, CA. August 4, 2004. 14 pages.

Hawkins, G. L., D. T. Hill, E. W. Rochester, and C. W. Wood. 1998. Evaluation of vegetative filter strips for swine lagoon wastewater. Transactions of the ASAE. 41(3): 639-643.

Harner, J. P. and P. K. Kalita. 1999. Vegetative filters for improving environmental quality. Cattlemen's Days 1999 conference proceedings. Kansas Agricultural Experiment Station. Kansas State University. pg 44-47.

Hubbard, R. K., R. R. Lawrence, J. G. Davis, and G. L. Newton. 1994. Removing nitrogen from swine waste using riparian zones. 1994 International ASAE Summer Meeting. ASAE Paper number 94-4070. 18 pages.

Hubbard, R. K., J. M. Ruter, G. L. Newton, and J. G. Davis. 1999. Nutrient uptake and growth response of six wetland/riparian plan species receiving swine lagoon effluent. Transactions of the ASAE. 42(5): 1331-1341.

Ikenberry, C.D. and K.R. Mankin. 2000. Review of vegetative filter strip performance for animal waste treatment. Presented at the 2000 ASAE Mid-Central Meeting, Paper No. MC00-128. American Society of Agricultural Engineers, St. Joseph, MI 49085.

Iowa Department of Natural Resources. 2004. Siting criteria: non-basin technology for waste treatment systems for open feedlots. Shared by Gene Tinkler, IDNR, by personal communications, July 2004. 9 pages.

Keaton, M.R., P. K. Kalita, J. P. Harner, S. K. Starrett. 1998. Evaluation of vegetative filter strips for nutrient removal from feedlot runoff. American Society of Agricultural Engineers. 1998 ASAE Annual International Meeting. Paper No. 98-2014. 20 pages.

Koelliker, J.K., H.L. Manges and R.I. Lipper. 1975. Modeling the performance of feedlot-runoff control facilities. Transactions of the ASAE.18 (6) 1118-1121

Komor, S. C. and D. S. Hansen. 2003. Attenuation of runoff and chemical loads in grass filter strips at two cattle feedlots, Minnesota, 1995-98. U. S. Geological Survey. Denver, CO. WaterResources Investigations Report 03-4036.15 pages.

Lim, T.T., D.R. Edwards, S.R. Workman and B.T. Larson. 1997. Vegetated filter strip length effects on quality of runoff from grazed pastures. Paper No. 97-2060. American Society of Agricultural Engineers, St. Joseph, MI 49085.

Lim, T.T., D.R. Edwards, S.R. Workman, a B.T. Larson and L. Dunn. 1998. Vegetated filter strip removal of cattle manure constituents in runoff. Transactions of the ASAE. 41(5):1375-1381.

Linderman, C. L. and L. N. Mielke. 1975. Irrigation with feedlot runoff. Nebraska short course irrigation proceedings. University of Nebraska. January 20-21, 1975. pg. 26-36. 
Lorimor, J.C., S.W. Melvin, and K. Adam. 1995. Settling basin performance from two outdoor feedlots. Presented at ASAE Mid Central Conference, St. Joseph, MO.

Lorimor, J. C., L. Wulf, and P. Jaranilla. 2003. An infiltration-wetland system for treating open feedlot runoff. Proceedings of the 9th International Symposium. ASAE. pp 405-410.

Lott, S.C., R.J. Loch, and P.J. Watts. 1994. Settling characteristics of feedlot cattle feces and manure. Transactions of the ASAE 37(1):281-285.

Mankin, K. R. and C. G. Okoren. 2003. Field evaluation of bacteria removal in a VHS. Paper No. 032150. Presented at 2003 ASAE Annual International Meeting, Las Vegas, NV. 9 pages.

Minnesota Pollution Control Agency. 2003. Vegetated infiltration areas and filter strips to treat feedlot runoff: interim guidelines. www.pca.state.mn.us/hot/feedlots. 12 pages.

Moffit, D., B. Wilson, P. Willey. 2003. Evaluating the design and management of waste storage ponds receiving lot runoff. 2003 ASAE Annual International Meeting. Paper no. 034129. 12 pages.

Monkus, V. 1964. Estimation of runoff from storm rainfall. Chapter 10. National Engineering Handbook. USDA NRCS Publication NEH Part 630-10 (ftp://ftp.wcc.nrcs.usda.gov/downloads/ hydrology_hydraulics/neh630/630ch10.pdf). 24 pages.

Montana NRCS. 2003. Analysis procedures for ag-waste collection basin/VFS. Montana Supplement to Chapter 10 of the Agricultural Waste Management Field Handbook.

Moore, J.A., R.O. Hegg, D.C. Scholz, and Egon Strauman. 1973. Settling solids in animal waste slurries. 1973 ASAE Annual International Meeting. ASAE paper number 73-438.

Murphy, J. P. and J. P. Harner. 1999. Runoff compliance for Kansas cattle feedlots. Cattlemen's Days 1999 conference proceedings. Kansas Agricultural Experiment Station. Kansas State University. pp. 40-43.

Murphy, P. and J. P. Harner. 2001. Open lot runoff management options. Livestock Poultry Environmental Stewardship curriculum, Lesson 22. http://www.LPES.org. 30 pages.

Murphy, T. J. and W. M. Bogovich. 2001. Vegetated filter areas for agricultural wastewater treatment. 2001 ASAE Annual International Meeting. ASAE paper number 012296. 12 pages.

MWPS. 1985. Livestock waste facilities Handbook. Midwest Plan Service Publication MWPS-18. Iowa State University, Ames, IA.

Nienaber, J. A., C. B. Gilbertson, T. M. McCalla and F. M. Kestner. 1974. Disposal of effluent from a beef cattle feedlot runoff control holding pond. Transactions of the ASAE. 17(2):375-378.

Nye, J. C. 1982. Runoff control fro livestock feedlots. Research results in manure digestion, runoff, refeeding, odors. North Central Regional Research Publication No. 284. Midwest Plan Service. p 10-17.

Overcash, M.R., S.C. Bingham and P.W. Westerman. 1981. Predicting runoff pollutant reduction in buffer zones adjacent to land treatment sites. Transactions of the ASAE. 24(2): 430-435.

Paterson, J.J., J. H. Jones, F. J. Olsen and G. C. McCoy. 1980. Dairy liquid waste distribution in an overland flow vegetative-soil filter system. Transactions of the ASAE. 23(4):973-978.

Pope, R. O. and D. E.Stoltenberg. 1991. A review of literature related to vegetative filter strips. Agronomy Department publication. Iowa State University, Ames, IA. 15 pages.

Prantner, S.R., R.S. Kanwar, J.C. Lorimor and C.H. Pederson. 2001. Soil infiltration and wetland microcosm treatment of liquid swine manure. Applied Engineering in Agriculture. 17(4):483488.

Sanderson, M. A., R. M. Jones, M. J. McFarland, J. Stroup, R. L. Reed and J. P., Muir. 2001. Nutrient movement and removal in a switchgrass biomass-filter strip system treated with dairy manure. J. Environ. Qual. 30(1):210-216.

Schellinger, G.R. and J.C. Clausen. 1992. Vegetative filter treatment of dairy barnyard runoff in cold regions. J. Environ. Qual. 21:40-45.

Schmitt, T. J., M. G. Dosskey and K. D. Hoagland. 1999. Filter strip performance and processes for different vegetation, widths, and contaminants. J. Environ. Qual. 28(5):1479-1489.

Schwer, C.B. and J.C. Clausen. 1989. Vegetative filter treatment of dairy milkhouse wastewater. $J$. Environ. Qual. 18:446-451.

Soil Conservation Service. 1992. Agricultural waste management field handbook. National Engineering Handbook. USDA Soil Conservation Service. http://www.wcc.nrcs.usda.gov/awm/ awmfh.html. 
Srivastava, P., D. R. Edwards, T. C. Daniel, P. A. Moore, Jr. and T. A. Costello. 1996. Performance of vegetative filter strips with varying pollutant source and filter strip lengths. Transactions of the ASAE. 39(6):2231-2239.

Swanson, N. P. and L.N. Mielke. 1973. Solids trap for beef cattle feedlot runoff. Transactions of the ASAE. 16(4):743-745.

Swanson, N. P., L. N. Mielke, J. C. Lorimor, T. M. McCalla and J. R. Ellis. 1971. Transport of pollutants from sloping cattle feedlots as affected by rainfall intensity, duration, and recurrence. Proceedings of the International Symposium on Livestock Wastes. ASAE., St. Joseph, Mich. pp. 51-55.

Sweeten, J.M. 1990. Feedlot runoff characteristics for land application. In Agricultural and Food Processing Waste. Proceedings of the 6th International Symposium on Agricultural and Food Processing Waste. ASAE. St. Joseph, MI. pp 168-184.

Sweeten, J. M. 1991. Cattle feedlot waste management practices for water and air pollution control. Texas Agricultural Extension Service. Texas A\&M University. College Station, TX. 24 pages.

Vanderholm, D. H. and E. C. Dickey. 1980 Design of vegetative filters for feedlot runoff treatment in humid areas. Transactions of the ASAE. 23(3):661-684.

Williamson, T.S. 1999. Effectiveness of vegetative filter strips in reducing fecal coliform from surface runoff. Unpublished Masters Thesis. Biological \& Agricultural Engineering. Kansas State University, Manhattan, KS.

Willrich, T.L. and J.O. Boda. 1976. Overland flow treatment of swine lagoon effluent. ASAE Paper No. 76-4515. St. Joseph, MI 49085.

Wilson, B, W. Boyd and D. Moffitt. 2003. AWM: A computer program for planning/design of manure and wastewater storage/treatment facilities. 2003 ASAE Annual Meeting. Paper no. 034160. 9 pages.

Woodbury, B. L., J. A. Nienaber and R. A. Eigenberg. 2003a. Sustainability of a passive feedlot runoff control system using a vegetative filter strip for nutrient control. Presented at the 2003 ASAE Annual International Meeting, Las Vegas, NV. Paper No. 032269.

Woodbury, B. L., J. A. Nienaber and R. A. Eigenberg. 2002. Operational evaluation of a passive beef cattle feedlot runoff control and treatment system. Applied Engineering in Agriculture, Volume 18 (5) 541-545.

Woodbury, B. L., J. A. Nienaber and R. A. Eigenberg. 2003b. Nitrogen management of a feedlot runoff control system with vegetative filter strip. Proceedings of the 9th International Symposium. pp 372-376.

Wulf, L. W., J. C. Lorimor and S. W. Melvin. 2003. Modifications to feedlot runoff containment systems in Iowa. Animal, Agricultural and Food Processing Wastes IX. Proceedings of the Ninth International Symposium. ASAE. St. Joseph, MI. pp. 387-396.

Wulf, L. W., J. C. Lorimor and S. W. Melvin. 2004. Modifications to feedlot runoff containment systems in Iowa. Paper submitted to Applied Engineering in Agriculture.

Yang, P. and J. Lorimor. 2000. Physical and chemical analysis of beef cattle feedlot runoff before and after soil infiltration and wetland treatment. Eighth International Symposium on Ag and Food Processing Wastes. Oct. 9-11, 2000. ASAE. St.Joseph, MI. pp. 203-209.

Younos, T. M., A. Mendez, E. R. Collins and B. B. Ross. 1998. Effects of a dairy loafing lot-buffer strip on stream waster quality. J. American Water Resources Association. 34(5):1061-1069.

Young, R. A., T. Huntrods and W. Anderson. 1980. Effectiveness of vegetated buffer strips in controlling pollution from feedlot runoff. J. Environ. Qual. 9(3)483-487.

Zhang, Q., C. G. Okoren and K. R. Mankin. 2001. Modeling fecal pathogen transport in vegetative filter strips. Presented at 2001 ASAE Annual International Meeting. Paper no. 012194. 16 pages. 